
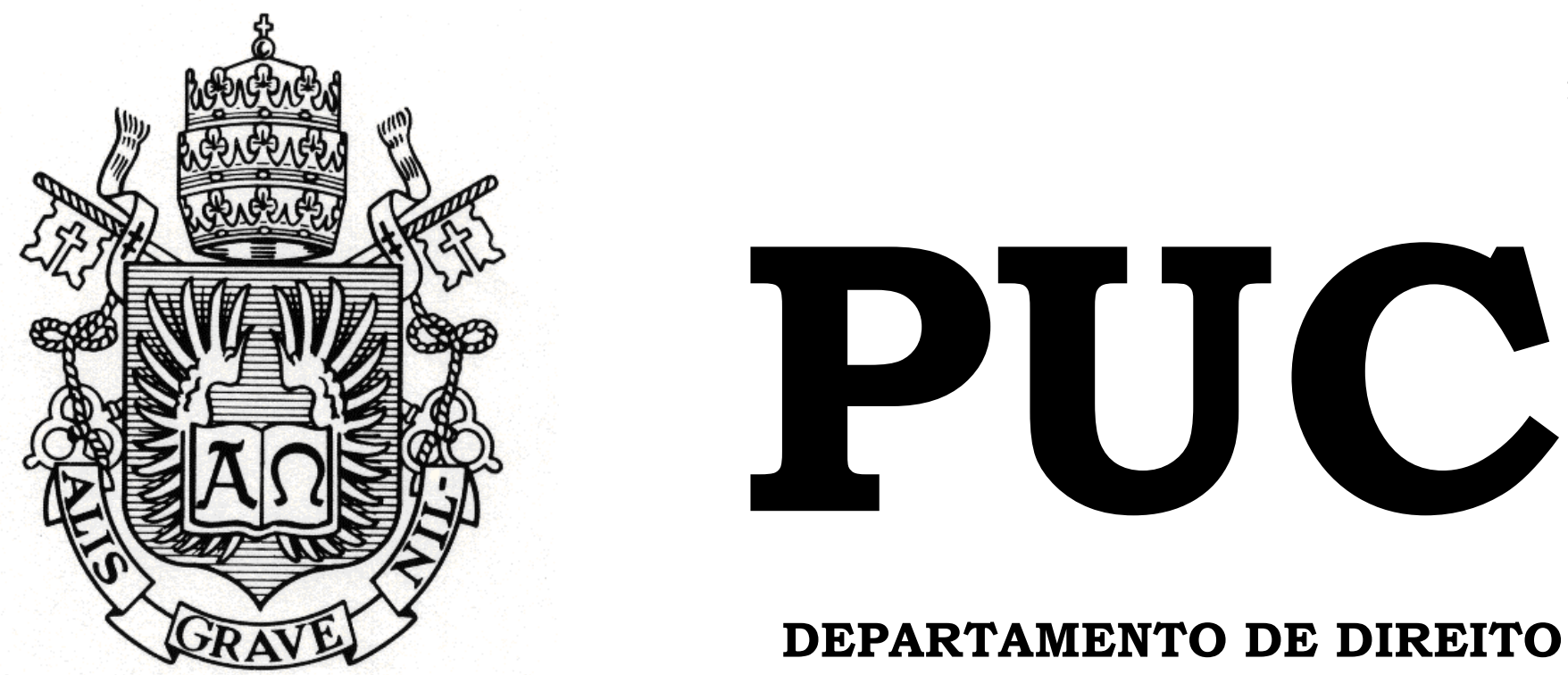

DEPARTAMENTO DE DIREITO

Reclamação Constitucional: aspectos teóricos e práticos

por

Daniel Galliza Simões Lorenzo Gonzalez

ORIENTADOR(A): Melvin Badra Bennesby

2009.1

PONTIFÍCIA UNIVERSIDADE CATÓLICA DO RIO DE JANEIRO RUA MARQUÊS DE SÃO VICENTE, 225 - CEP 22453-900 RIO DE JANEIRO - BRASIL 


\title{
Reclamação Constitucional: aspectos teóricos e práticos
}

\author{
por
}

\section{Daniel Galliza Simões Lorenzo Gonzalez}

Monografia apresentada ao Departamento de Direito da Pontificia Universidade Católica do Rio de Janeiro (PUC-Rio) para a obtenção do Título de Bacharel em Direito.

Orientador(a): Melvin Badra Bennesby 
Aos meus pais, Jane e Dino, meus verdadeiros mestres, de quem espero ter herdado o senso de dignidade, solidariedade e honestidade, pelo amor inesgotável, pelo apoio incondicional e por ensinar o certo e o errado.

Nunca poderei retribuir tanto. Amo vocês!

A minha família, meus avós, minhas tias e meus tios, com amor, por confiarem em mim, até mesmo quando eu hesito. Agradeço a Deus, pelo privilégio de tê-los em minha vida. À Juliana, minha namorada, com quem compartilho, mais que amor, o cotidiano, os estudos e as incertezas do amanhã, pelo companheirismo e por me inspirar a querer ser sempre mais. Obrigado por tudo. Não há vitória sem sacrifícios. 


\section{Agradecimentos}

Agradeço a todos que contribuíram nessa caminhada, pessoas que foram protagonistas nesses capítulos da minha própria história e que, independentemente da distância, jamais poderei esquecer. Primeiramente, meu mais sincero obrigado ao Professor Melvin Bennesby, a quem admiro por sua seriedade e dedicação, cuja orientação foi imprescindível para a elaboração deste trabalho. Não poderia deixar de citar meus amigos de PUC-Rio, graduandos e graduados, pessoas maravilhosas como Bruno Rousso, Gustavo Marse, Rodrigo Dieguez, Rafael "Big" Gonçalves, Rita de Cássia, Tatiana Balderrama, João Marcos, a galera do "banco" e tantos outros que só pude conhecer graças à rotina estudantil. Não posso esquecer meus colegas de PGE/RJ e JUCERJA, com quem divido minhas tardes e que tanto me apoiaram enquanto finalizava a presente monografia. Por fim, reitero o dito na dedicatória, a fim de agradecer infinitamente a minha família, meu porto seguro, especialmente a Dino, Jane, Celina, Paulo, Gina, Kith, Janice, Juliana, Róbson e Josué. 
"You, the people, have the power to make this life free and beautiful, to make this life a wonderful adventure. Then, in the name of democracy, let us use that power - let us all unite! Let us fight for a new world, a decent world, that will give men a chance to work, that will give you the future and old age security."

(Charles Chaplin, em “O Grande Ditador”, filme de 1940) 


\section{Resumo}

A presente monografia discute o tema da reclamação constitucional. $O$ trabalho foi dividido em oito capítulos: o primeiro é introdutório, trazendo apontamentos iniciais necessários; o segundo analisa as origens do instituto e seu desenvolvimento no direito brasileiro; o terceiro capítulo debate a controvérsia acerca da natureza jurídica da medida e seus efeitos práticos; o quarto analisa o objeto e o cabimento da reclamação, com especial enfoque no que exorta a doutrina e a jurisprudência; o quinto capítulo versa sobre a competência para processamento e julgamento do instituto; o sexto capítulo trata da legitimidade ativa e passiva em sede reclamacional; o sétimo capítulo trata do rito da reclamação, instituído pela Lei $n^{\circ} 8.038 / 90$ e pelos Regimentos Internos dos Tribunais; e, por fim, o oitavo capítulo cuida das questões finais do tema e as conclusões do autor.

Palavras - chave: reclamação constitucional; origem; natureza jurídica; objeto; cabimento; procedimento; legitimidade; teoria dos poderes implícitos. 


\section{Sumário}

1 - Notas introdutórias

2 - Origem da reclamação e consagração pelo direito brasileiro.........................11

2.1 - Antecedentes históricos .................................................................11

2.2 - Reclamação no direito brasileiro.........................................................11

2.2.1) Construção jurisprudencial e a doutrina dos poderes

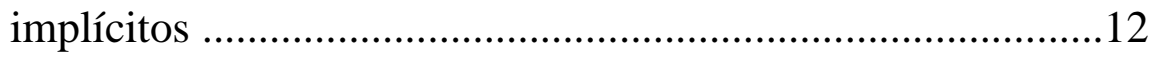

2.2.2) Previsão regimental ..............................................................16

2.2.3) Carta Magna de 1967 ..........................................................18

2.2.4) Constituição da República de 1988............................................20

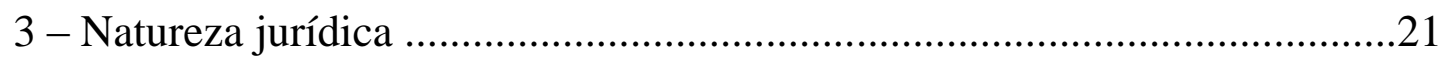

3.1 - Discussão doutrinária e jurisprudencial ............................................21

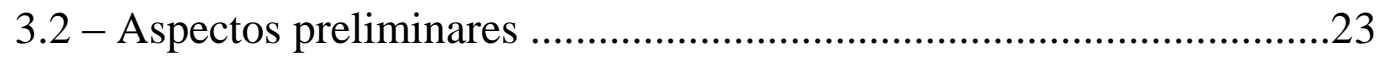

3.2.1) Medida administrativa ou jurisdicional ..................................23

3.2.2) Jurisdição contenciosa ou voluntária .......................................26

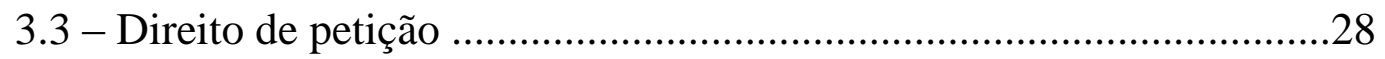

3.3.1) A posição do STF: ADI 2.212/CE e ADI

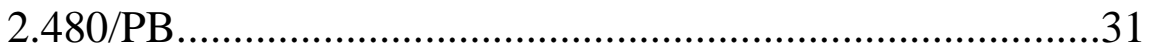

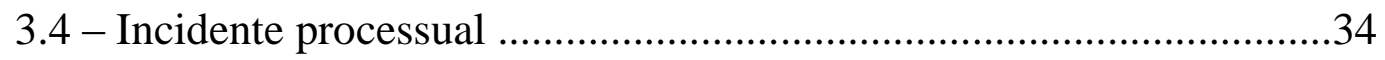

3.4.1) A posição do STJ ...................................................................36

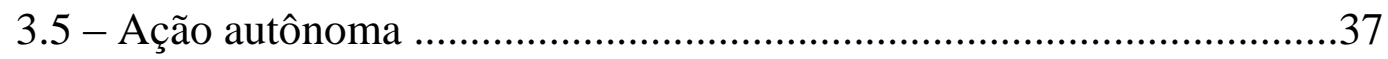

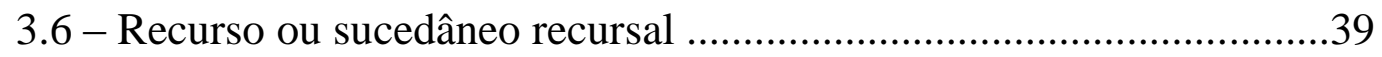

3.7 - Remédio processual e outros definições genéricas ............................42 
3.8 - Efeitos da definição da natureza jurídica do

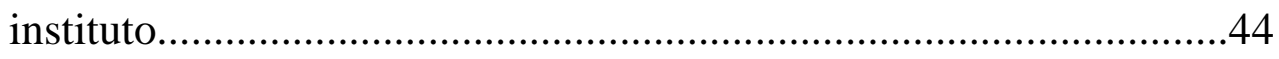

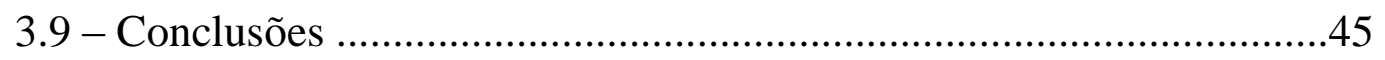

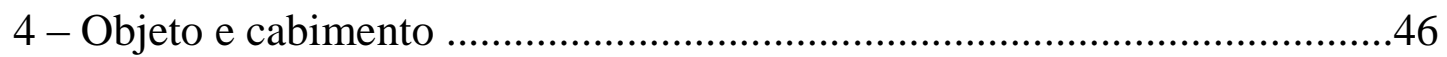

4.1 - Preservação de competência do tribunal ...........................................49

4.2 - Garantia da autoridade das decisões do tribunal ...............................50

4.2.1) Reclamação contra ato judicial transitado em julgado: a súmula 734 do STF ..............................................................

4.2.2) Reclamação como sucedâneo de recurso ou ação impugnativa específica …....................................................50

4.2.3) Reclamação e o princípio da instrumentalidade das formas

4.2.4) Reclamação contra ato de autoridade administrativa que afronta a autoridade de decisão do Tribunal proferida em processo subjetivo 52

4.2.5) A garantia da autoridade das decisões do STF proferidas em controle concentrado de constitucionalidade .56

4.2.5.1) A teoria da transcendência dos motivos determinantes .57

4.3 - Garantia do escorreito cumprimento de súmula vinculante .59

4.3.1) Reclamação e a súmula tradicional .60

4.3.2) $\mathrm{O}$ esgotamento das vias administrativas como pressuposto de admissibilidade de reclamação 


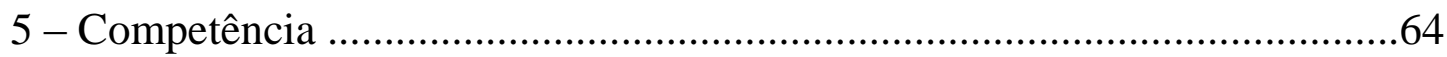

5.1 - Supremo Tribunal Federal e Superior Tribunal de Justiça ...................64

5.2 - Tribunais de Justiça e Tribunais Regionais Federais ............................66

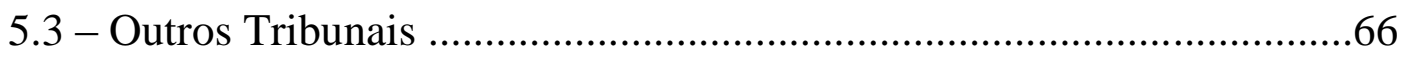

5.3.1) Superior Tribunal Militar ………………................................66

5.3.2) Tribunal Superior do Trabalho .................................................66

5.3.3) Tribunal Superior Eleitoral ...................................................67

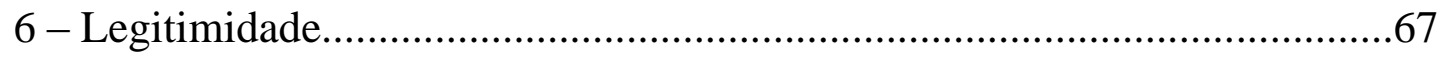

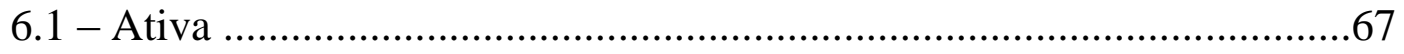

6.1.1) Capacidade postulatória ........................................................69

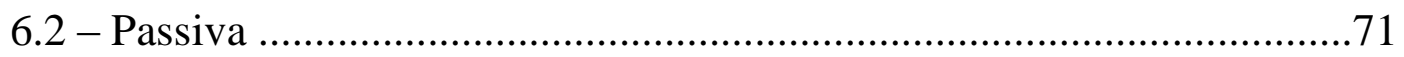

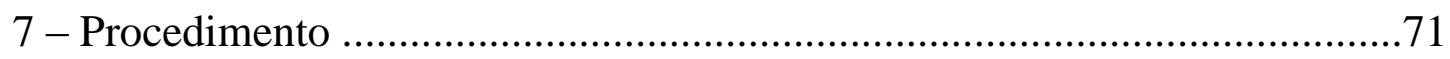

7.1 - Fase postulatória ……………..........................................................

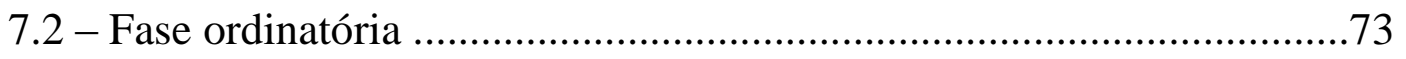

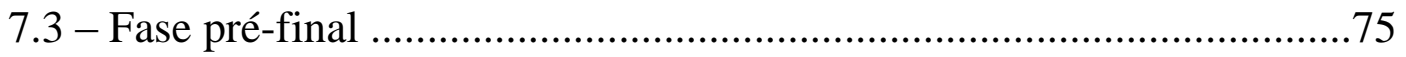

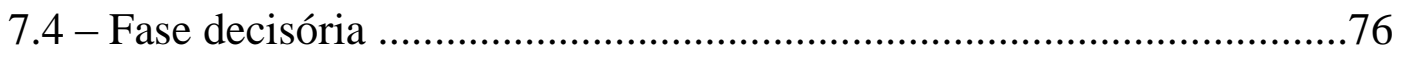

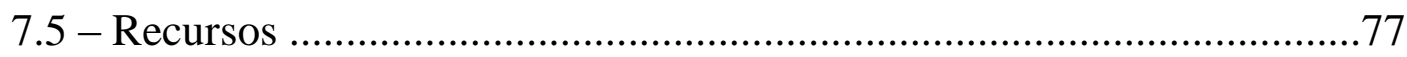

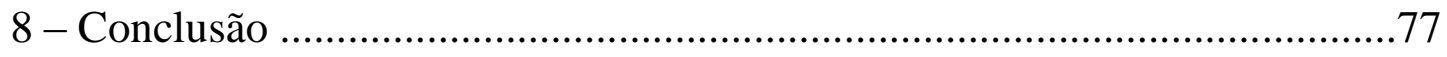

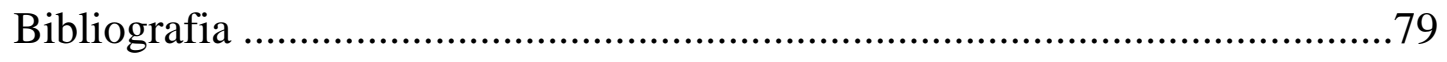




\section{Notas introdutórias}

A reclamação constitucional, instituto previsto nos arts. 102, I, $l, 103-\mathrm{A}$, $\S 3^{\circ}$, e $105, \mathrm{I}, f$, da CRFB/88, e regulada pela Lei $\mathrm{n}^{\circ}$ 8.038/90, é um instrumento de controle e defesa da autoridade das decisões, de competência originária dos Tribunais Superiores, cuja consagração no direito brasileiro se deu, inicialmente, por construção pretoriana ${ }^{1}$.

O instituto tem como escopo a preservação da competência do tribunal, a garantia da autoridade de suas decisões e o fiel cumprimento de verbete sumular com caráter vinculante.

Todavia, não deve ser confundido com a correição parcial, também denominada de reclamação correcional, instrumento de controle disciplinar da atividade do magistrado no curso do processo, portanto, com caráter eminentemente administrativo, com a finalidade de correção, pelo tribunal superior, de ato tumultuário do juiz.

Reveste-se de maior relevância o instituto quando se verifica a evolução da reclamação na prática forense. Segundo dados do STF, somente em 2008, foram distribuídas 1.625 e julgadas outras 2.346 reclamações naquela Corte, enquanto que, em 1998, dez anos antes, apenas 275 reclamações foram distribuídas e 120 julgadas $^{2}$.

Ademais, a pouca importância dada ao estudo do instituto pelos tradicionais manuais e cursos de direito processual civil e de direito constitucional, não obstante a interdisciplinaridade da matéria, evidencia a precariedade da análise do tema, que é estudado de forma verticalizada apenas

\footnotetext{
${ }^{1}$ Cf. GRINOVER, Ada Pellegrini et al. Da reclamação aos tribunais. Doutrina. Rio de Janeiro: Instituto de Direito, v.12, 2001, p. 123.

2 Segundo estatísticas exibidas no próprio sítio do STF, disponível em: <http://www.stf.jus.br/portal/cms/verTexto.asp?servico=estatistica\&pagina=pesquisaClasse>. Acessado em 20.03.2009.
} 
por ensaios jurídicos que tratam exclusivamente do tema, como monografias e artigos jurídicos.

Nesse sentido, buscou-se compilar e analisar, no presente trabalho, o maior número de informações e entendimentos da doutrina autorizada sobre os diversos aspectos da medida, que se encontram, de forma esparsa em determinados estudos, imprimindo caráter didático à presente monografia.

Com efeito, considerando o cenário contemporâneo onde os sistemas teoricamente paradoxais da common law e da civil law tendem à gradual convergência, procurou-se assentar o estudo não só na doutrina autorizada, mas também nas principais decisões - leading cases - dos Tribunais Superiores.

No entanto, as decisões do STF e do STJ, em sede de reclamação constitucional, por vezes, são casuísticas, objetivando, tão somente, a solução das questões trazidas à análise dos Tribunais, prescindindo de uma abordagem teórica do instituto em si, como instrumento legal e alvo de interesse acadêmico.

Registre-se, contudo, que alguns arestos, como a ADI 2.212, um dos principais julgados do STF sobre o tema, são dotados de grande importância acadêmica, acrescentando à produção científica.

Portanto, pretende-se produzir um trabalho monográfico acerca da reclamação constitucional, com alcance vertical, abordando os aspectos teóricos e procedimentais da medida, sob o prisma da doutrina e da jurisprudência.

Tem-se, ainda, uma preocupação constante com a utilidade prática deste estudo, razão pela qual restou imprescindível a abordagem de questões controvertidas, como a natureza jurídica da reclamação, bem como uma análise sistematizada do seu procedimento no âmbito dos Tribunais Superiores. 


\section{Origem da reclamação e consagração pelo direito brasileiro}

\subsection{Antecedentes históricos}

A questão dos antecedentes históricos da reclamação nem sempre é tratada de forma uniforme pela doutrina.

Na tese defendida por JOSÉ DA SILVA PACHECO, afirma-se que os institutos como a suplicatio, do Direito Romano, o agravo de ordenação não guardada, das Ordenações Filipinas, e o agravo por dano irreparável, do Brasil Imperial, influenciaram na consagração da reclamação ${ }^{3}$.

Todavia, na visão de MARCELO NAVARRO RIBEIRO DANTAS, nem esses institutos, nem mesmo o aparecimento do mandado de segurança, tiveram relevância para a criação da reclamação, que foi produto exclusivo da construção jurisprudencial do Supremo Tribunal Federal com amparo na teoria dos poderes implícitos ${ }^{4}$.

\subsection{Reclamação no Direito brasileiro}

A doutrina, capitaneada por JOSÉ DA SILVA PACHECO ${ }^{5}$, com frequiência sistematiza a evolução histórica da reclamação constitucional no ordenamento jurídico brasileiro em quatro fases diferentes.

\footnotetext{
${ }^{3}$ PACHECO, José da Silva. O mandado de segurança e outras ações constitucionais típicas. $4^{\text {a }}$. ed. rev. atual. e ampl. São Paulo: Editora Revista dos Tribunais, 2002, p. 603.

${ }^{4}$ DANTAS, Marcelo Navarro Ribeiro. Reclamação Constitucional no Direito Brasileiro. Porto Alegre: Sergio Antonio Fabris Editor, 2000, p. 51-52.

${ }^{5}$ PACHECO, José da Silva. A reclamação no STF e no STJ de acordo com a nova Constituição. Revista dos Tribunais. São Paulo: RT, v. 646, ano 78, p. 19, ago. 1989. No mesmo sentido: GRINOVER, Ada Pellegrini. Da Reclamação. Revista Brasileira de Ciências Criminais. São Paulo: Revista dos Tribunais, v. 9, n. 38, p. 75, abr./jun. 2002; SANTOS, Alexandre Moreira Tavares dos. Da
} 
Adotando-se essa estrutura sistêmica, insta abordar cada período evolutivo-histórico, destacando suas principais características e os leading cases na jurisprudência do STF.

\subsubsection{Construção jurisprudencial e a doutrina dos poderes implícitos}

A primeira fase, ou fase de formulação ${ }^{6}$, abrange o período compreendido desde a criação do Supremo Tribunal Federal (STF) até a consagração do instituto no Regimento Interno da Corte, em 1957, é caracterizada primordialmente pela falta de previsão da reclamação no âmbito do direito positivo.

Nesse primeiro momento, não existia qualquer menção em dispositivos constitucionais ou legais à medida, o que não impediu a consagração do instituto por construção jurisprudencial do STF, com o objetivo de solucionar diversos problemas concretos. ${ }^{7}$

Destarte, o entendimento da Corte se assentava no pressuposto de que, não obstante a ausência de texto legal permissivo, seria ínsito à sua própria competência constitucional assegurar a efetividade das suas decisões e garantir a sua competência constitucional, principalmente em razão da posição hierárquica que aquele Tribunal ocupa no ordenamento jurídico pátrio, utilizando a reclamação, como instrumento próprio para essa finalidade.

Reclamação. Revista dos Tribunais. São Paulo: Revista dos Tribunais, ano 92, v. 808, p. 122-123, fev. 2003. Acrescentando mais uma fase à evolução histórica: DANTAS, Marcelo Navarro Ribeiro. Reclamação Constitucional no Direito Brasileiro. Porto Alegre: Sergio Antonio Fabris Editor, 2000, p. 45-48.

${ }^{6}$ Nomenclatura adotada em: DANTAS, Marcelo Navarro Ribeiro. Reclamação Constitucional no Direito Brasileiro. Porto Alegre: Sergio Antonio Fabris Editor, 2000, p. 46.

${ }^{7}$ MENDES, Gilmar Ferreira. A Reclamação Constitucional no Supremo Tribunal Federal: Algumas Notas. Revista Direito Público. Porto Alegre: Síntese, v. 3, n. 12, p. 21, abr./jun. 2006. 
Tal posicionamento encontra amparo na doutrina dos poderes implícitos ou implied powers, teoria de caráter eminentemente hermenêutico, elaborada pela jurisprudência da Suprema Corte dos Estados Unidos da América a partir de decisões em casos de grande repercussão, que tem origem na escola clássica do constitucionalismo norte-americano.

O princípio dos poderes implícitos, doutrina embrionária da atual teoria da máxima eficácia constitucional, rezava que devem ser entendidos como implícitos os meios necessários para o exercício de uma competência constitucionalmente prevista, desde que não expressamente proibidos.

Nesse diapasão, a doutrina destaca importante lição de Madison, no Federalista, n. XLIV:

"Desde que um fim é reconhecido necessário, os meios são permitidos, todas as vezes que é atribuída uma competência geral para fazer alguma coisa, nela estão compreendidos todos os particulares poderes necessários para realizá-la." 8

Com ineditismo, o Chief Justice John Marshall foi conclusivo ao dizer que "se o fim é legitimo e está de acordo com os objetivos da Constituição, todos os meios apropriados e plenamente adaptáveis a ele, não proibidos, mas dentro da letra e do espírito da Constituição, são constitucionais"9.

Analisando a influência do constitucionalismo americano no direito brasileiro, inclusive nas decisões do Supremo Tribunal, LÊDA BOECHAT RODRIGUES prescreve:

"Por força da adoção do regime federativo no Brasil, tornaram-se a Constituição, a jurisprudência e as autoridades constitucionais americanas, a partir da doutrinação de Rui Barbosa, fontes de interpretação entre nós. Nenhum debate constitucional

\footnotetext{
${ }^{8}$ PACHECO, José da Silva. A reclamação no STF e no STJ de acordo com a nova Constituição. Revista dos Tribunais. São Paulo: RT, v. 646, ano 78, p. 20, ago. 1989.

${ }^{9}$ Traduzido em RODRIGUES, Lêda Boechat. A Corte Suprema e o Direito Constitucional Americano. Rio de Janeiro: Forense, 1958, p.44-45 apud DANTAS, Marcelo Navarro Ribeiro. Reclamação Constitucional no Direito Brasileiro. Porto Alegre: Sergio Antonio Fabris Editor, 2000, p. 160.
} 
importante, desde então e até hoje, nenhum constitucionalista ou publicista que se preze, nenhuma grande decisão do Supremo Tribunal Federal passou ou passa sem a citação de precedentes ou de constitucionalistas americanos." 10

Nesse passo, observa-se a influência da pena de Marshall no clássico voto do Ministro Rocha Lagoa, relator da Reclamação no 141, julgada em 25 de janeiro de 1952, revelando a adoção do princípio dos implied powers pelo Supremo Tribunal Federal ${ }^{11}$ :

"A competência não expressa dos tribunais federais pode ser ampliada por construção constitucional. Vão seria o poder, outorgado ao Supremo Tribunal Federal de julgar em recurso extraordinário as causas decididas por outros tribunais, se lhe não fora possível fazer prevalecer os seus próprios pronunciamentos, acaso desatendidos pelas justiças locais. A criação dum remédio de direito para vindicar o cumprimento fiel das suas sentenças, está na vocação do Supremo Tribunal Federal e na amplitude constitucional e natural de seus poderes. Necessária e legítima é assim a admissão do processo de Reclamação, como o Supremo Tribunal tem feito. É de ser julgada procedente a Reclamação quando a justiça local deixa de atender a decisão do Supremo Tribunal Federal."

Registre-se, ainda, que, além do princípio hermenêutico, contribuíram para a criação pretoriana do instituto o surgimento da figura típica do mandado de segurança e a previsão do direito fundamental de petição pela Lei Maior ${ }^{12}$, bem como a liberdade trazida pela Constituição de 1946 ao STF, pondo fim ao regime constitucional estabelecido preteritamente pelo Estado Novo. ${ }^{13}$

Sinteticamente, JOSÉ DA SILVA PACHECO aponta, ao seu ver, as influências essenciais da denominada fase de formulação:

10 RODRIGUES, Lêda Boechat. A Corte Suprema e o Direito Constitucional Americano. Rio de Janeiro: Forense, 1958, p.12-13 apud DANTAS, Marcelo Navarro Ribeiro. Reclamação Constitucional no Direito Brasileiro. Porto Alegre: Sergio Antonio Fabris Editor, 2000, p. 160-161.

11 Apud MENDES, Gilmar Ferreira. A Reclamação Constitucional no Supremo Tribunal Federal: Algumas Notas. Revista Direito Público. Porto Alegre: Síntese, v. 3, n. 12, p. 21-22, abr./jun. 2006

12 PACHECO, José da Silva. O mandado de segurança e outras ações constitucionais típicas. $4^{\mathrm{a}}$. ed. rev. atual. e ampl. São Paulo: Editora Revista dos Tribunais, 2002, p. 604.

13 DANTAS, Marcelo Navarro Ribeiro. Reclamação Constitucional no Direito Brasileiro. Porto Alegre: Sergio Antonio Fabris Editor, 2000, p. 171-172. 
"Foi marcada, principalmente, pela influência: a) do princípio dos poderes implícitos, proclamado e reconhecido pela Corte norte-americana; b) do Direito Romano, em que se admitia a suplicatio, a partir da cognitio extra ordine; do nosso Direito antigo, em que se contemplava o agravo de ordenação não guardada, conforme Ordenações Filipinas, Livro III, tít. XX, $\$ 46$, e Livro I, tít. V, $\$ 4{ }^{\circ}$; e do agravo por dano irreparável do Regulamento 737, de 25.11.1850; c) do direito de organização judiciária dos Estados, que incluía a correição parcial, principalmente pela do antigo Distrito Federal; d) do mandado de segurança contra atos de autoridade judicial, a partir de 1934; e) do atentado contra ato judiciário." 14

Ademais, a relevância da reclamação para o STF, já naquela época, era indiscutível, vez que, diferentemente dos tribunais ordinários que realizavam o controle da efetividade de suas decisões e dos atos dos magistrados a eles subordinados através dos recursos previstos na legislação processual, o STF, enquanto instância extraordinária, ficaria limitado a fazê-lo por falta de expressa previsão legal ${ }^{15}$.

No que tange à jurisprudência do STF, insta apontar que a reclamação, embora consagrada pela tese vencedora, não era unanimidade nessa fase inicial.

Alguns ministros daquela Corte como Hahnemann Guimarães, Mário Guimarães e Abner de Vasconcellos, partidários da tese minoritária, contrapunham-se à utilização da medida. Para o Ministro Hahnemann Guimarães, a reclamação era inadmissível, por falta de expressa previsão legal e por se tratar de instituto diverso da correição parcial, esta última aceita pelo STF e com caráter essencialmente administrativo. ${ }^{16}$

\footnotetext{
${ }^{14}$ PACHECO, José da Silva. A reclamação no STF e no STJ de acordo com a nova Constituição. Revista dos Tribunais. São Paulo: RT, v. 646, ano 78, p. 20, ago. 1989. No sentido da influência exclusiva da teoria dos poderes implícitos: DANTAS, Marcelo Navarro Ribeiro. Reclamação Constitucional no Direito Brasileiro. Porto Alegre: Sergio Antonio Fabris Editor, 2000, p. 51-52.

${ }^{15}$ SANTOS, Alexandre Moreira Tavares dos. Da Reclamação. Revista dos Tribunais. São Paulo: Revista dos Tribunais, ano 92, v. 808, p. 124, fev. 2003.

${ }^{16}$ PACHECO, José da Silva. O mandado de segurança e outras ações constitucionais típicas. $4^{\text {a }}$. ed. rev. atual. e ampl. São Paulo: Editora Revista dos Tribunais, 2002, p. 605.
} 
Acrescente-se que a jurisprudência do STF ainda não distinguia claramente a reclamação da correição parcial ou reclamação correicional, não obstante os votos do Ministro Hahnemann Guimarães.

Relativamente à possibilidade de reclamação em âmbito estadual, o STF entendia como inconstitucional a previsão do instituto por leis estaduais de organização judiciária, por não ser possível a ampliação da lei processual por legislação estadual.

Em 1948, no julgamento do Recurso Extraordinário nº 11.543, o STF declarou a inconstitucionalidade de dispositivo que criava, no âmbito do Judiciário Baiano, a figura da reclamação em nível estadual. ${ }^{17}$

Uma vez feitas essas considerações, é de se observar que a consagração jurisprudencial da reclamação gradativamente conduziria à sua positivação, como simples reflexo da evolução histórica e do amadurecimento da medida na prática forense, o que, por sua vez, colocaria termo à fase inicial do seu histórico evolutivo.

\subsubsection{Previsão regimental}

O advento da trigésima sessão do Tribunal Pleno do STF, em 2 de outubro de 1957, marca o começo da segunda fase ou fase de discussão ${ }^{18}$ da reclamação no ordenamento jurídico nacional.

Naquela sessão foi deliberada e aprovada, a proposta de emenda ao Regimento Interno da Suprema Corte (RISTF), apresentada pelo Ministro

\footnotetext{
${ }^{17}$ SANTOS, Alexandre Moreira Tavares dos. Da Reclamação. Revista dos Tribunais. São Paulo: Revista dos Tribunais, ano 92, v. 808, p. 124, fev. 2003.

18 DANTAS, Marcelo Navarro Ribeiro. Reclamação Constitucional no Direito Brasileiro. Porto Alegre: Sergio Antonio Fabris Editor, 2000, p. 46.
} 
Ribeiro da Costa, que previa a inserção da reclamação com a criação do capítulo V-A, denominado "Da Reclamação", no título III, do RISTF"19.

Nesse passo, segue-se, em parte, a justificativa para inserção do instituto no RISTF, dada pelo proponente, Ministro Ribeiro da Costa:

"A medida processual de caráter acentuadamente disciplinar e correcional denominada reclamação, embora não prevista, de modo expresso, no art. 101, $n^{o}$ s I a IV, da Constituição Federal, tem sido admitida pelo Supremo Tribunal Federal, em várias oportunidades, exercendo-se, nesses casos, sua função corregedora, a fim de salvaguardar a extensão e os efeitos de seus julgados, em cumprimento dos quais se avocou legítima e oportuna intervenção". ${ }^{20}$

Assim, o STF, atuando na esteira da competência que lhe era atribuída pelo art. 97, II, da Constituição de 1946, foi responsável por positivar, ainda que pela via regimental, o instituto da reclamação pela primeira vez na história do direito brasileiro, ampliando, de certa forma, a competência expressa ex vi do art. 101, I a IV da Constituição Federal de $1946^{21}$.

Cumpre destacar que o RISTF previa um rito mais célere para a reclamação do que o atualmente estipulado. Isso porque o prazo para o reclamado prestar informações era de apenas 48 horas $\left(\operatorname{art.} 3^{\circ}, \S 1^{\circ}\right.$ ), e a reclamação, após a devolução dos autos pelo relator, deveria ser incluída na pauta da primeira sessão do Tribunal (art. $\left.4^{\circ}\right)$.

Quanto à jurisprudência, importante destacar decisão exarada na ReclP $\mathrm{n}^{\mathrm{o}} 371^{22}$, julgada em 1959, na qual restou consignada a impossibilidade de

\footnotetext{
${ }^{19}$ MENDES, Gilmar Ferreira. A Reclamação Constitucional no Supremo Tribunal Federal: Algumas Notas. Revista Direito Público. Porto Alegre: Síntese, v. 3, n. 12, p. 22-23, abr./jun. 2006.

${ }^{20}$ Apud MENDES, Gilmar Ferreira. A Reclamação Constitucional no Supremo Tribunal Federal: Algumas Notas. Revista Direito Público. Porto Alegre: Síntese, v. 3, n. 12, p. 22, abr./jun. 2006.

${ }^{21}$ GRINOVER, Ada Pellegrini. A reclamação para garantia da autoridade das decisões dos tribunais. Revista Síntese de Direito Penal e Processo Penal. Porto Alegre: Síntese, v.1, n.2, p. 12, jun./jul. 2000.

${ }^{22}$ RTJ 10.01, p. 503 apud DANTAS, Marcelo Navarro Ribeiro. Reclamação Constitucional no Direito Brasileiro. Porto Alegre: Sergio Antonio Fabris Editor, 2000, p. 171-172.
} 
ampliação de determinada decisão a casos semelhantes, pela via da reclamação.

Ressalte-se que, como pertinentemente observa MARCELO NAVARRO RIBEIRO DANTAS, ainda não havia sido introduzida a ação direta de inconstitucionalidade, e, por conseguinte, o efeito erga omnes das decisões, no ordenamento jurídico brasileiro ${ }^{23}$.

\subsubsection{Carta Magna de 1967}

A terceira fase histórica tem início com a "promulgação" da Constituição de 1967, que deu novos entornos à questão do regimento interno do STF, vez que o seu art. 115, parágrafo único, $c$, dispunha que o RISTF estabeleceria "o processo e o julgamento dos feitos de sua competência originária ou de recurso" ${ }^{24}$.

Posteriormente, a previsão constitucional seria mantida, apesar das reformas impostas à Lei Maior pela Emenda Constitucional no 1 , de 1969, e pela $E C \mathrm{n}^{\circ} 7$, de 1977, ficando prevista respectivamente no art. 115, parágrafo único, $c$, e no art. $119, \S 3^{\circ}, c$.

A EC $n^{\circ} 7$ inseria, no texto constitucional, a controvertida figura da avocatória, que conferia ao STF a competência para avocar as causas processadas perante qualquer juízo, quando deferisse pedido do Procurador Geral da República (art. 119, I,o).

Em virtude da questão da avocatória, MARCELO NAVARRO RIBEIRO DANTAS, divergindo da sistemática clássica sugerida por JOSÉ DA SILVA PACHECO e pontualmente adotada por outros doutrinadores,

\footnotetext{
23 DANTAS, Marcelo Navarro Ribeiro. Reclamação Constitucional no Direito Brasileiro. Porto Alegre: Sergio Antonio Fabris Editor, 2000, p. 193.

${ }^{24}$ Disponível em <http://www.planalto.gov.br/ccivil_03/constituicao/Constitui\%C3\%A7ao67.htm>. Acesso em 10 mar. 2009.
} 
vislumbra duas fases - e não apenas uma - no período compreendido entre a "promulgação" da Carta Constitucional de 1967 até o advento da Constituição de 1988.

O período compreendido entre a Carta de 1967 e a EC n ${ }^{\circ} 7$, na visão de MARCELO NAVARRO RIBEIRO DANTAS, seria a chamada fase de consolidação, enquanto que o período subseqüente, cujo termo se dá com a promulgação da Constituição de 1988, seria a denominada fase de definição do instituto $^{25}$. Segundo o aludido autor, essa distinção é válida em virtude da relevância da avocatória, na seara de estudo da reclamação, vez que "se adotada para fins de preservação da competência da Corte, esvaziaria parcialmente a reclamatória", ainda que somente quatro avocatórias tenham sido concedidas pelo STF. $^{26}$

A principal discussão jurisprudencial dessa fase restringia-se à exclusividade ou não do Supremo Tribunal para previsão regimental do instituto.

ADA PELLEGRINI GRINOVER ${ }^{27}$ destaca que o STF, na Representação $\mathrm{n}^{\mathrm{o}}$ 1.092-DF, concluiu pela inconstitucionalidade de dispositivo regimental do extinto Tribunal Federal de Recursos que previa o instituto da reclamação.

$\mathrm{Na}$ referida representação, julgada em 1986, a OAB/DF questionava a constitucionalidade dos arts. 194 a 201 do Regimento Interno do TFR, que previam e disciplinavam a competência originária daquele tribunal para conhecimento e julgamento de reclamação.

25 DANTAS, Marcelo Navarro Ribeiro. Reclamação Constitucional no Direito Brasileiro. Porto Alegre: Sergio Antonio Fabris Editor, 2000, p. 47.

${ }^{26}$ DANTAS, Marcelo Navarro Ribeiro. Reclamação Constitucional no Direito Brasileiro. Porto Alegre: Sergio Antonio Fabris Editor, 2000, p. 223.

${ }^{27}$ GRINOVER, Ada Pellegrini. Da Reclamação. Revista Brasileira de Ciências Criminais. São Paulo: Revista dos Tribunais, v. 9, n. 38, p. 76-77, abr./jun. 2002. 
A tese vencedora, no sentido da procedência da representação, fundouse na premissa de que somente ao STF foi constitucionalmente atribuída a competência para estabelecer, em sede regimental, o instituto, não previsto na legislação processual, tratando-se, portanto, de poder reservado exclusivamente à Corte Suprema ${ }^{28}$.

\subsubsection{Constituição da República de 1988}

O início da quarta e atual fase da reclamação é caracterizado com a promulgação da CRFB de 1988. O sistema constitucional vigente consagrou o instituto da reclamação, prevendo-o expressamente nos seus arts. 102, I, $l$, e $105, \mathrm{I}, f$.

Com efeito, inovou também o novo texto constitucional ao prever a competência originária do STF e do STJ para julgamento do instituto. Assim, viabilizou-se, positivamente, a utilização da reclamação por outro órgão jurisdicional diverso da Corte Suprema.

ADA PELLEGRINI GRINOVER ${ }^{29}$ leciona que restaram superadas discussões anteriormente levantadas sobre a exclusividade do STF relativamente à reclamação, considerando a estatura constitucional atribuída ao instituto, a extensão da competência para julgamento do remédio, ora instituído dentre as atribuições do STJ, e a preocupação contemporânea de garantir, não só os direitos fundamentais, mas a ampla efetivação da proteção a esses direitos.

\footnotetext{
${ }^{28}$ PACHECO, José da Silva. O mandado de segurança e outras ações constitucionais típicas. $4^{\text {a }}$. ed. rev. atual. e ampl. São Paulo: Editora Revista dos Tribunais, 2002, p. 608.

${ }^{29}$ GRINOVER, Ada Pellegrini. A reclamação para garantia da autoridade das decisões dos tribunais. Revista Síntese de Direito Penal e Processo Penal. Porto Alegre: Síntese, v.1, n.2, p. 14, jun./jul. 2000.
} 
Outrossim, a nova Constituição tornou sem efeito as discussões sobre a constitucionalidade do instituto, ante a falta de previsão em legislação processual $^{30}$.

A Lei Federal $n^{\circ}$ 8.038/90 instituiu, em seus arts. 13 a 18, normas procedimentais no âmbito da reclamação, estipulando o prazo de 10 (dez) dias para apresentação de informações pela autoridade reclamada (art. 14, I), bem como possibilitando ao relator a suspensão liminar do ato impugnado, quando houver perigo de dano irreparável (art. 14, II).

No que se refere à jurisprudência contemporânea, importantes debates residem numa definição quanto à natureza jurídica do instituto e suas implicações, no que divergem STF, STJ e a própria doutrina, conforme será analisado no próximo capítulo.

\section{Natureza jurídica}

\subsection{Discussão doutrinária e jurisprudencial}

A definição da natureza jurídica da reclamação nunca foi tarefa de fácil solução. Não há, até hoje, apesar de doutas opiniões, unanimidade sobre o assunto entre os juristas, razão pela qual não se pode prescindir de um estudo do tema.

Evidentemente, a conjuntura histórica marca individualmente cada uma das correntes doutrinárias surgidas com o passar do tempo: as teses elaboradas vão ser pautadas inegavelmente pelo contexto social, político e econômico de sua época, bem como pelo grau de positivação do instituto. Em outras palavras,

\footnotetext{
${ }^{30}$ PACHECO, José da Silva. O mandado de segurança e outras ações constitucionais típicas. $4^{\mathrm{a}}$. ed. rev. atual. e ampl. São Paulo: Editora Revista dos Tribunais, 2002, p. 609.
} 
a forma como a doutrina interpreta o instituto e sua natureza jurídica guarda relação com as fases históricas da reclamação ${ }^{31}$.

Com efeito, apesar de alguns julgados isolados, o STF demorou a enfrentar diretamente o tema, tanto é que, na Reclamação $n^{\mathbf{o}} 831-\mathrm{DF}^{32}$, o Ministro AMARAL SANTOS observou a ausência de "deliberação assente do egrégio STF quanto à natureza jurídica da reclamação", concluindo pela natureza recursal do instituto.

Todavia, foi a partir da promulgação da Constituição Federal de 1988, quando o texto legal concedeu status constitucional à reclamação, que o STF, o STJ e a própria doutrina passaram a se manifestar mais claramente sobre o tema, firmando, inclusive, posicionamentos diferentes.

Nesse passo, a título de ilustração, veja-se que o entendimento atual da Corte Constitucional, no mesmo sentido das lições de ADA PELLEGRINI GRINOVER $^{33}$, insere o instituto no campo do direito de petição ${ }^{34}$, enquanto que o Superior Tribunal de Justiça vê a reclamação como um incidente processual $^{35}$, na esteira de MONIZ DE ARAGÃO ${ }^{36}$.

Diante da latente controvérsia, faz-se mister tecer algumas considerações sobre as correntes autorizadas que permeiam o tema.

\footnotetext{
${ }^{31}$ Cumpre oportunamente registrar que a divisão histórica da reclamação no direito brasileiro em quatro fases, proposta por JOSÉ DA SILVA PACHECO (PACHECO, José da Silva. O mandado de segurança e outras ações constitucionais típicas. $4^{a}$ ed. rev., atual. e ampl. São Paulo: Editora Revista dos Tribunais, 2002, p. 601-610) e adotada neste trabalho, refere-se à intensidade da positivação desse remédio no ordenamento jurídico pátrio.

${ }^{32}$ STF, Rcl 831, Relator Ministro Amaral Santos, TRIBUNAL PLENO, julgado em 11/11/1970, DJ 19/02/1971.

33 GRINOVER, Ada Pellegrini; GOMES FILHO, Antonio Magalhães; FERNANDES, Antonio Scarance. Recursos no processo penal. $6^{a}$ ed. rev, atual. e ampl. São Paulo: Editora Revista dos Tribunais, 2009, p. 336-338.

${ }^{34}$ Entendimento consolidado a partir da ADI no 2.212-CE (cf. itens 3.3 e 3.3.1).

${ }^{35}$ Ver itens 3.4 e 3.4.1.

${ }^{36}$ ARAGÃO, Egas Dirceu Moniz de. A correição parcial. São Paulo: Bushatsky, 1969, p. 110 apud PACHECO, José da Silva. O mandado de segurança e outras ações constitucionais típicas. $4^{\mathrm{a}}$ ed. rev., atual. e ampl. São Paulo: Editora Revista dos Tribunais, 2002. p. 621.
} 


\subsection{Aspectos preliminares}

A respeito da natureza jurídica, surgem duas indagações freqüentemente analisadas de forma preliminar, consistindo-se em saber se a reclamação teria essência administrativa ou jurisdicional, e, em outro plano, se seria jurisdição contenciosa ou voluntária.

Faz-se precípuo, nesse momento, apontar soluções a estas perguntas, o que será de suma importância para facilitar a classificação do instituto em um tipo jurídico, mormente no fornecimento de subsídios necessários à formação de uma perspectiva quanto à sua natureza jurídica.

\subsubsection{Medida administrativa ou jurisdicional?}

Nesse primeiro ponto, opera-se a seguinte indagação: a reclamação é uma medida administrativa ou jurisdicional?

A tese doutrinária minoritária sustenta a natureza não-jurisdicional da reclamação. Modernamente, ADA PELLEGRINI GRINOVER fundamenta a sua posição no entendimento de que o escopo da reclamação seria garantir a eficácia de uma prestação jurisdicional já obtida, afastando expressamente o exercício da jurisdição, que já teria ocorrido preteritamente ${ }^{37}$. Com efeito, a opinio da eminente professora é congruente com a sua conclusão, de que a natureza da reclamação residiria no campo do direito de petição ${ }^{38}$.

\footnotetext{
37 GRINOVER, Ada Pellegrini; GOMES FILHO, Antonio Magalhães; FERNANDES, Antonio Scarance. Recursos no processo penal. $6^{\mathrm{a}}$ ed. rev, atual. e ampl. São Paulo: Editora Revista dos Tribunais, 2009, p. 337.

38 GRINOVER, Ada Pellegrini; GOMES FILHO, Antonio Magalhães; FERNANDES, Antonio Scarance. Recursos no processo penal. $6^{a}$ ed. rev, atual. e ampl. São Paulo: Editora Revista dos Tribunais, 2009, p. 337.
} 
Anote-se aqui que, ainda nas primeiras fases históricas do instituto, essa teoria era freqüentemente verificada na jurisprudência do STF, mas sob fundamento completamente diferente do atualmente defendido pela eminente jurista, uma vez que, naquela época, ainda havia certa confusão entre correição parcial e reclamação.

De outro ângulo, a corrente majoritária milita pela natureza jurisdicional do instituto, trazendo a baila diversos fundamentos a justificar a sua posição.

Com efeito, alega-se, a fim de justificar essa posição, que caso tivesse a reclamação natureza administrativa, prescindiria o instituto de previsão constitucional expressa na competência originária do STF e do STJ, já que as medidas de natureza administrativa podem ser tratadas exclusivamente pelos regimentos internos dessas Cortes, ante o seu poder de auto-organização ${ }^{39}$. Importa observar que, considerando-se a função judicante como a atividade típica dos órgãos jurisdicionais, a competência manifesta-se exatamente como uma parcela da jurisdição a ser exercida por um ou mais órgãos do Poder Judiciário $^{40}$.

A jurisprudência, consolidada a partir de inúmeros precedentes do Pretório Excelso, tem exigido a capacidade postulatória, isto é, tem-se como obrigatória a representação da parte ou interessado por um advogado ou defensor $^{41}$. De outro lado, não se exige a capacidade postulatória em âmbito administrativo.

\footnotetext{
${ }^{39}$ DANTAS, Marcelo Navarro Ribeiro. Reclamação constitucional no direito brasileiro. Porto Alegre: Sergio Antonio Fabris Editor, 2000, p. 435-436.

${ }^{40}$ MARINONI, Luiz Guilherme; ARENHART, Sérgio Cruz. Curso de processo civil, volume 2: processo de conhecimento. $6^{a}$ ed. rev., atual. e ampl. São Paulo: Editora Revista dos Tribunais, 2009, p.37.

${ }^{41}$ STF, Rcl 729/SP, Rel. Min. Marco Aurélio (Rel. para acórdão: Min. Nelson Jobim), Pleno, julgamento em 09/09/1998, DJ 24/03/2006.
} 
Ademais, a Lei Federal $\mathrm{n}^{\circ}$ 8.038/90, haja vista o seu art. 13, II, possibilita, em sede reclamacional, a concessão de liminar cautelar ${ }^{42}$, que é modalidade de tutela jurisdicional ${ }^{43}$.

Admite-se o cabimento de recursos judiciais, in casu, embargos de declaração, agravo interno (ou "regimental"), recurso especial e recurso extraordinário das decisões proferidas em reclamação. Assim, estaria afastada a natureza administrativa do instituto, pois das decisões administrativas são cabíveis recursos administrativos, e não recursos tipicamente jurisdicionais ${ }^{44}$.

Corrobora com a tese o fato de que a reclamação somente é processada mediante provocação do órgão jurisdicional competente pelos legitimados (art. 13, da Lei $n^{\text {o }}$ 8.038/90). Verifica-se que opera uma das características da jurisdição, a inércia. Diversamente, os atos administrativos podem ser revistos ex officio (ou, ainda, a requerimento), posto que fosse a reclamação uma medida administrativa, poderiam os tribunais, por si só, instaurá-las, com base no poder hierárquico ou no poder disciplinar ${ }^{45}$.

Traçando um paralelo diferencial entre a reclamação e a correição parcial, que tem caráter eminentemente administrativo, aduz MARCELO NAVARRO RIBEIRO DANTAS:

"A correição parcial, em princípio, é requerida, provocada. Mas, dentro do poder correicional geral, é claro que as corregedorias e os órgãos da administração judiciária não só podem como devem fazer correições, tanto gerais como parciais, sempre que entenderem necessário reprimir abusos ou equívocos dos órgãos judiciários sob sua supervisão. E o fazem. Sequer é necessário consultar as leis de organização judiciária ou os regimentos internos dos tribunais, nem sendo preciso

\footnotetext{
${ }^{42}$ Existe uma divergência doutrinária sobre a natureza jurídica dessa liminar. Para uns, trata-se de tutela antecipada, para outros, cautelar.

${ }^{43}$ DANTAS, Marcelo Navarro Ribeiro. Reclamação constitucional no direito brasileiro. Porto Alegre: Sergio Antonio Fabris Editor, 2000, p. 439.

${ }^{44}$ MORATO, Leonardo Lins. A reclamação prevista na Constituição Federal. In: ALVIM, Eduardo Pellegrini de Arruda; NERY JR., Nelson; WAMBIER, Teresa Arruda Alvim (Coord.). Aspectos polêmicos e atuais dos recursos. São Paulo: Editora Revista dos Tribunais, 2000, p. 446.

${ }^{45}$ DINAMARCO, Cândido Rangel. A Reclamação no processo civil brasileiro. Seleções Jurídicas $A D V$. Rio de Janeiro: COAD, dez. 2001, p. 1.
} 
falar nos regulamentos e normas internas de menor hierarquia, para comprovar essa asserção." 46

Vale trazer ainda outro argumento, no sentido de que a reclamação, admitida sua natureza administrativa, só poderia atingir atos emanados por órgãos do Poder Judiciário, sob pena de inconstitucionalidade, sendo discutível, ainda, se os Tribunais Federais poderiam, através da reclamação, atingir atos de órgãos jurisdicionais estaduais, ante a autonomia federativa ${ }^{47}$.

Além do mais, o ato de cassar uma decisão judicial, como ocorre quando da procedência de reclamação fundada na hipótese de descumprimento de decisão do tribunal ou de violação de enunciado de súmula vinculante, seria atividade exclusivamente jurisdicional, senão estar-se-ia admitindo a sujeição de ato jurisdicional a ato administrativo, o que seria inconstitucional ${ }^{48}$.

Assim sendo, verifica-se a relevância dessa argüição preliminar, uma vez que adotada a corrente majoritária, no sentido do caráter jurisdicional da reclamação, só se poderia concluir pela inclusão do instituto em três tipos jurídicos: ação, recurso (ou sucedâneo recursal) ou incidente processual.

\subsubsection{Jurisdição contenciosa ou voluntária}

Caso seja adotada a tese que sustenta o caráter judicial da reclamação, urge analisar uma nova controvérsia: a reclamação é jurisdição contenciosa ou voluntária?

\footnotetext{
${ }^{46}$ DANTAS, Marcelo Navarro Ribeiro. Reclamação constitucional no direito brasileiro. Porto Alegre: Sergio Antonio Fabris Editor, 2000, p. 436.

${ }^{47}$ DANTAS, Marcelo Navarro Ribeiro. Reclamação constitucional no direito brasileiro. Porto Alegre: Sergio Antonio Fabris Editor, 2000, p. 437-438.

${ }^{48}$ MORATO, Leonardo Lins. A reclamação prevista na Constituição Federal. In: ALVIM, Eduardo Pellegrini de Arruda; NERY JR., Nelson; WAMBIER, Teresa Arruda Alvim (Coord.). Aspectos polêmicos e atuais dos recursos. São Paulo: Editora Revista dos Tribunais, 2000, p. 445.
} 
A doutrina majoritária tem militado pela primeira hipótese, sob o entendimento de que existe lide na reclamação, bem como há a instauração de contraditório entre as partes, o que teria sido evidenciado a partir da edição da Lei ${ }^{\circ} 8.038 / 90 .^{49}$

Por outro ângulo, o Ministro ROMILDO BUENO DA SILVA já havia se manifestado, embora implicitamente, defendendo a natureza de jurisdição voluntária do instituto. Confira-se a passagem, costumeiramente mencionada pela doutrina:

"A reclamação, em verdade, não constitui processo. Nela não há autor nem réu; nela não há pedido, conseqüentemente, não há litígio, embora possa haver controvérsia. São, contudo, coisas absolutamente diversas. Trata-se de mero e singelo procedimento. Procedimento, aliás, destinado apenas a possibilitar ao tribunal, pelo conhecimento de ato atentatório de sua competência, defender e manter suas decisões." 50

De qualquer sorte, deve-se observar ainda que acerca da jurisdição voluntária existem basicamente duas teorias, cujas lições resultaram em efeitos práticos, caso seja interpretada a reclamação como típica jurisdição voluntária.

Sem embargo, vislumbrando-se a reclamação como jurisdição voluntária a partir da conceituação fornecida pela teoria clássica (ou administrativista) da jurisdição, isso importará necessariamente na sua definição como medida administrativa ${ }^{51}$. Explica-se: a teoria administrativista não vislumbra na jurisdição voluntária a existência de um processo, mas de um procedimento, por considerar basicamente que nessa espécie de "jurisdição" não se busca a composição de uma lide; por não ser voltada a discussão de

\footnotetext{
${ }^{49}$ MORATO, Leonardo Lins. A reclamação prevista na Constituição Federal. In: ALVIM, Eduardo Pellegrini de Arruda; NERY JR., Nelson; WAMBIER, Teresa Arruda Alvim (Coord.). Aspectos polêmicos e atuais dos recursos. São Paulo: Editora Revista dos Tribunais, 2000, p. 446.

${ }^{50}$ Apud PACHECO, José da Silva. O mandado de segurança e outras ações constitucionais típicas. $4^{\mathrm{a}}$ ed. rev., atual. e ampl. São Paulo: Editora Revista dos Tribunais, 2002. p. 619.

${ }^{51}$ DANTAS, Marcelo Navarro Ribeiro. Reclamação constitucional. In: FARIAS, Cristiano Chaves de; DIDIER JR., Fredie (Coord.). Procedimentos especiais cíveis: legislação extravagante. São Paulo: Saraiva, 2003, p. 339.
} 
direitos anteriores, mas de situações jurídicas novas; e, por não ser substitutiva, isto é, porque a atuação jurisdicional não estaria substituindo a atividade das partes $^{52}$.

Assim, em síntese, para a teoria clássica, a jurisdição voluntária tem natureza administrativa, afastando-se a feição jurisdicional que lhe impõe a teoria revisionista, resultado de uma concepção que não admite processo sem litígio $^{53}$.

Por outro lado, para os adeptos da teoria revisionista, a jurisdição voluntária corresponderia ao exercício da atividade jurisdicional típica, vez que o que caracterizaria o processo seria a pretensão, como resultado da inércia, não o litígio ${ }^{54}$. Logo, sob essa ótica, seria possível classificar a reclamação como processo (propriamente dito) de jurisdição voluntária, sem lhe negar, então, o seu caráter judicial.

\subsection{Direito de petição}

O direito de petição é um instrumento de controle administrativo, consagrado constitucionalmente como um direito de postulação do indivíduo aos órgãos públicos, em prol da defesa de direitos ou contra ilegalidade ou abuso de poder ${ }^{55}$.

\footnotetext{
${ }^{52}$ CÂMARA, Alexandre Freitas. Lições de direito processual civil - volume I. $12^{\mathrm{a}}$ ed., rev. e atual. segundo o Código Civil de 2002 e pela Emenda Constitucional 45/2004. Rio de Janeiro: Editora Lumen Juris, 2005, p. 78-79.

${ }^{53}$ CÂMARA, Alexandre Freitas. Lições de direito processual civil - volume I. $12^{\mathrm{a}}$ ed., rev. e atual. segundo o Código Civil de 2002 e pela Emenda Constitucional 45/2004. Rio de Janeiro: Editora Lumen Juris, 2005, p. 79-80.

${ }^{54}$ CÂMARA, Alexandre Freitas. Lições de direito processual civil - volume I. $12^{\mathrm{a}}$ ed., rev. e atual. segundo o Código Civil de 2002 e pela Emenda Constitucional 45/2004. Rio de Janeiro: Editora Lumen Juris, 2005, p. 80-81.

${ }^{55}$ CARVALHO FILHO, José dos Santos. Manual de direito administrativo. $18^{\mathrm{a}}$ ed. Rio de Janeiro: Editora Lumen Júris, 2007, p. 833-834.
} 
Com efeito, suas raízes históricas residem na Inglaterra Medieval, com o advento do Bill of Rights de 1689. Essa declaração de direitos consagrou o right of petition, instrumento que concedia ao povo o acesso ao monarca através de petição, posteriormente contemplado pela Declaração de Direitos da Pensilvânia de 1776, e pela Constituição Francesa de $1791^{56}$.

No direito brasileiro moderno, o direito de petição está contemplado no art. 5, XXXIV, “a”, da Constituição de 1988, caracterizando-se, na pena de ALEXANDRE DE MORAES, como "instrumento de participação políticofiscalizatória dos negócios do Estado que tem por finalidade a defesa da legalidade constitucional e do interesse público geral", assegurado a qualquer pessoa $^{57}$.

Portanto, o direito de petição caracteriza-se como um instrumento legal que possibilita ao cidadão comum alertar formalmente ao Poder Público a ocorrência de uma arbitrariedade.

O Ministro NELSON HUNGRIA, no julgamento da Rcl. $\mathrm{n}^{\mathrm{o}} 141^{58}$, rejeitou a natureza recursal do instituto, definindo-o como uma representação ao STF contra o abuso ocorrido. Cumpre ressaltar que o novo texto constitucional adotou a nomenclatura de "direito de petição" abarcando o antigo conceito de "direito de representação" contemplado pelas Constituições anteriores $^{59}$.

ADA PELLEGRINI GRINOVER explica que nem sempre ao recorrer ao Poder Judiciário necessariamente o postulante esteja exercitando o direito de ação, pois que, em certas situações, pode se tratar de uma garantia mais ampla, como o direito de petição:

\footnotetext{
${ }^{56}$ MORAES, Alexandre de. Direito constitucional. $21^{\text {a }}$ ed. São Paulo: Atlas, 2007, p.169.

${ }^{57}$ MORAES, Alexandre de. Direito constitucional. $21^{\text {a }}$ ed. São Paulo: Atlas, 2007, p.170.

${ }^{58}$ STF, Rcl 141/SP, Rel. Min. Barros Barreto, Tribunal Pleno, julgamento em 03/11/1952, DJ 29/01/1953.

${ }^{59}$ GRINOVER, Ada Pellegrini. Da Reclamação. Revista Brasileira de Ciências Criminais. São Paulo: Revista dos Tribunais, v. 9, n. 38, p. 80, abr./jun. 2002.
} 
"É o que ocorre claramente quando se cuida da reclamação aos tribunais, com o objetivo de assegurar a autoridade de suas decisões: não se trata de ação, uma vez que não se vai rediscutir a causa com um terceiro; não se trata de recurso, pois a relação processual já está encerrada, nem se pretende reformar a decisão, mas antes garanti-la; não se trata de incidente processual, porquanto o processo já se encerrou. Cuida-se simplesmente de postular perante o próprio órgão que proferiu uma decisão o seu exato e integral cumprimento.", 60

Das lições da ilustre jurista foi extraído o atual posicionamento do E. STF, que também põe a reclamação como corolário da garantia constitucional de petição. ${ }^{61}$

\section{No entanto, FREDIE DIDIER JR. e LEONARDO JOSÉ CARNEIRO} DA CUNHA criticam a inclusão da reclamação nessa seara, por entender que o exercício do direito de petição implicaria em uma atividade administrativa, o que não coadunaria com a essência do instituto ${ }^{62}$.

Note-se que esse ponto principal culminará nas diversas críticas feitas à posição defendida pela ilustre processualista (e adotada pelo Supremo Tribunal Federal). ADA PELLEGRINI GRINOVER entende que o direito de petição é um instrumento legal de significativa complexidade, do qual, inclusive, se extrairia o direito de ação, enquanto que, para FREDIE DIDIER JR., o direito de petição pode ser exercido também em atividade administrativa, o que o diferenciaria da reclamação, que só pode exercida na seara jurisdicional ${ }^{63}$.

\footnotetext{
${ }^{60}$ GRINOVER, Ada Pellegrini. Da Reclamação. Revista Brasileira de Ciências Criminais. São Paulo: Revista dos Tribunais, v. 9, n. 38, p. 80, abr./jun. 2002.

${ }^{61}$ Também militante dessa corrente: LENZA, Pedro. Direito constitucional esquematizado. $12^{\mathrm{a}}$ ed. rev., atual. e ampl. São Paulo: Saraiva, 2008, p. 209-210.

${ }^{62}$ DIDIER JR., Fredie; CUNHA, Leonardo José Carneiro da. Curso de Direito Processual Civil. Meios de impugnação às decisões judiciais e processo nos tribunais. Salvador: JusPodivm, 2008, p. 448.

${ }^{63}$ Por essa razão, RIBEIRO DANTAS diz que o conceito "incide em vagueza, uma vez que esse instituto abrange não só o direito de dirigir-se administrativamente a qualquer órgão público, como o direito de ação" (DANTAS, Marcelo Navarro Ribeiro. Reclamação constitucional no direito brasileiro. Porto Alegre: Sergio Antonio Fabris Editor, 2000, p. 432).
} 
Nesse diapasão, CÂNDIDO RANGEL DINAMARCO rejeitando a inclusão da reclamação no âmbito do direito de petição, ressalta que sendo a cassação da decisão o efeito principal da decisão de procedência da reclamação, esta tem natureza tipicamente jurisdicional, uma vez que medidas administrativas não teriam o condão de tornar ineficazes atos jurisdicionais. Além disso, destaca que se a reclamação realmente fosse dotada de natureza administrativa, não haveria a necessidade de provocação da parte interessada ou do Ministério Público para a sua instauração ${ }^{64}$, podendo o tribunal atuar ex officio. ${ }^{65}$

\subsubsection{A posição do STF: ADI 2.212-1/CE e ADI 2.480/PB}

Com o advento da ADI 2.212/CE ${ }^{66}$, quando o STF decidiu pela constitucionalidade de previsão da reclamação no âmbito dos tribunais

\footnotetext{
${ }^{64}$ Dessa forma, reproduz os mesmos motivos esposados por outros doutrinadores para justificar a impertinência de se considerar a reclamação como uma medida administrativa, conforme já demonstrado no presente trabalho (cf. item 3.2.1).

${ }^{65}$ DINAMARCO, Cândido Rangel. A reclamação no processo civil brasileiro. In: NERY JUNIOR, Nelson; WAMBIER, Teresa Arruda Alvim (Coord). Aspectos polêmicos e atuais dos recursos e de outros meios de impugnação às decisões judiciais. Série aspectos polêmicos e atuais dos recursos, v. 6 . São Paulo: Editora Revista dos Tribunais, 2002, p. 102-103.

66 "AÇÃO DIRETA DE INCONSTITUCIONALIDADE. ARTIGO 108, INCISO VII, ALÍNEA I DA CONSTITUIÇÃO DO ESTADO DO CEARÁ E ART. 21, INCISO VI, LETRA J DO REGIMENTO DO TRIBUNAL DE JUSTIÇA LOCAL. PREVISÃO, NO ÂMBITO ESTADUAL, DO INSTITUTO DA RECLAMAÇÃO. INSTITUTO DE NATUREZA PROCESSUAL CONSTITUCIONAL, SITUADO NO ÂMBITO DO DIREITO DE PETIÇÃO PREVISTO NO ARTIGO $5^{\circ}$, INCISO XXXIV, ALÍNEA A DA CONSTITUIÇÃO FEDERAL. INEXISTENNCIA DE OFENSA AO ART. 22, INCISO I DA CARTA. 1. A natureza jurídica da reclamação não é a de um recurso, de uma ação e nem de um incidente processual. Situa-se ela no âmbito do direito constitucional de petição previsto no artigo $5^{o}$, inciso XXXIV da Constituição Federal. Em conseqüência, a sua adoção pelo Estado-membro, pela via legislativa local, não implica em invasão da competência privativa da União para legislar sobre direito processual (art. 22, I da CF). 2. A reclamação constitui instrumento que, aplicado no âmbito dos Estados-membros, tem como objetivo evitar, no caso de ofensa à autoridade de um julgado, o caminho tortuoso e demorado dos recursos previstos na legislação processual, inegavelmente inconvenientes quando já tem a parte uma decisão definitiva. Visa, também, à preservação da competência dos Tribunais de Justiça estaduais, diante de eventual usurpação por parte de Juízo ou outro Tribunal local. 3. A adoção desse instrumento pelos Estados-membros, além de estar em sintonia com o princípio da simetria, está em consonância com o princípio da efetividade das decisões judiciais. 4. Ação direta de inconstitucionalidade improcedente." (STF, ADI 2212, Relatora Min. ELLEN GRACIE, Tribunal Pleno, julgado em 02/10/2003, DJ 14/11/2003).
} 
estaduais, houve uma guinada no posicionamento adotado anteriormentepela Corte no julgamento da Representação $\mathrm{n}^{\circ} 1.092 / \mathrm{DF}^{67}$, quando firmou entendimento no sentido da exclusividade do STF para julgar reclamações.

Na referida ação direta de inconstitucionalidade estava em discussão a constitucionalidade do art. 108, VII, $i$, da Constituição do Estado do Ceará e do art. 21, VI, $j$, do Regimento Interno do Tribunal de Justiça daquele Estado, que previam a competência originária daquele Tribunal de Justiça para processamento e julgamento de reclamação.

Com efeito, o cerne da questão estaria em considerar a reclamação como tendo natureza de processo, o que levaria à inconstitucionalidade dos dispositivos impugnados em razão da competência privativa da União (art. 22, I, da CF), ou como não tendo natureza processual, conforme alegou, em seu voto, o Ministro MARCO AURÉLIO DE MELO, que lhe atribuía o status de mero procedimento, ex vi do art. $24, \mathrm{XI}$, da CF. ${ }^{68}$

67 "INSTITUTO QUE NASCEU DE UMA CONSTRUÇÃO PRETORIANA, VISANDO A PRESERVAÇÃO, DE MODO EFICAZ, DA COMPETÊNCIA E DA AUTORIDADE DOS JULGADOS DO SUPREMO TRIBUNAL FEDERAL. SUA INCLUSÃO A 2.10.57, NO REGIMENTO INTERNO DO ÓRGÃO MAIOR NA HIERARQUIA JUDICIAL E QUE DESFRUTA DE SINGULAR POSIÇÃO. PODER RESERVADO EXCLUSIVAMENTE AO SUPREMO TRIBUNAL FEDERAL PARA LEGISLAR SOBRE "O PROCESSO E O JULGAMENTO DOS FEITOS DE SUA COMPETÊNCIA ORIGINARIA OU RECURSAL", INSTITUIDO PELA CONSTITUIÇÃO FEDERAL DE 1967 (ART-115, PARAGÚNICO, LETRA C, HOJE ART-119, PAR-3., LETRA C). COMO QUER QUE SE QUALIFIQUE RECURSO, AÇÃO, OU MEDIDA PROCESSUAL DE NATUREZA EXCEPCIONAL, E INCONTESTÁVEL A AFIRMAÇÃO DE QUE SOMENTE AO SUPREMO TRIBUNAL FEDERAL EM FACE PRIMACIALMENTE, DA PREVISÃO INSERIDA NO ART-119, PAR-3., LETRA "C", DA CONSTITUIÇÃO DA REPÚBLICA, E DADO NO SEU REGIMENTO INTERNO, CRIAR TAL INSTITUTO, NÃO PREVISTO NAS LEIS PROCESSUAIS. O REGIMENTO INTERNO DO TRIBUNAL FEDERAL DE RECURSOS AO CRIAR A RECLAMAÇÃO, NOS SEUS ARTS. 194 A 201, "PARA PRESERVAR A COMPETENNCIA DO TRIBUNAL OU GARANTIR A AUTORIDADE DAS SUAS DECISÕES", VULNEROU OS PRECEITOS CONSTANTES DO ART-43 C/C O ART-8., INC-XVII, LETRA B, ART-6. E SEU PARÁGRAFO ÚNICO, E DO ART-119, PAR-3., LETRA C, DA LEI MAGNA. REPRESENTAÇÃO JULGADA PROCEDENTE, POR MAIORIA DE VOTOS.” (STF, Rp 1092, Relator Min. DJACI FALCÃO, Tribunal Pleno, julgado em 31/10/1984, DJ 19/12/1984)

${ }^{68}$ COSTA, Hélio Rubens Batista Ribeiro. Reclamação nos tribunais estaduais. Revista de Processo. São Paulo: Ed. Revista dos Tribunais, ano 27, v. 105, jan./mar. 2003, p. 318-319. 
Inicialmente, sob a relatoria do então Ministro OCTAVIO GALLOTTI, foi parcialmente deferida medida cautelar para sustar os efeitos dos dispositivos, tendo sido acolhido o antigo posicionamento do $\mathrm{STF}^{69}$.

Com a aposentadoria do Ministro OCTAVIO GALLOTTI, a relatoria passou à responsabilidade da Ministra ELLEN GRACIE, que, utilizando os ensinamentos de ADA PELLEGRINI GRINOVER, concluiu pela inclusão do instituto na seara do direito de petição, o que a levou concluir pela constitucionalidade dos dispositivos em análise.

A corrente vencedora ${ }^{70}$ sustentou a constitucionalidade da inclusão da reclamação na competência originária dos tribunais de justiça locais, por não entendê-la como processo, razão pela qual seriam aplicáveis o princípio da simetria e a teoria dos poderes implícitos.

No entanto, os ministros MOREIRA ALVES, MAURÍCIO CORRÊA e SYDNEY SANCHES, adeptos da tese vencida, votaram pela natureza eminentemente processual da reclamação, o que implicaria na competência privativa da União para legislar sobre o instituto, nos termos do art. 22, I, da Constituição Federal.

Contudo, apesar da divergência na ADI 2.212-1/CE, atualmente a questão parece restar pacificada no STF. Tanto que no julgamento da ADI 2.480/PB, em 02.04.2007, o Tribunal afirmou a constitucionalidade de norma regimental que previa a reclamação no âmbito do Tribunal de Justiça Estadual, reafirmando a natureza jurídica de direito de petição do instituto ${ }^{71}$.

69 “Criação, por norma de Constituição estadual ou do Regimento do Tribunal de Justiça, de reclamação destinada à preservação da competência deste, ou à garantia de suas decisões. Relevância jurídica da argüição, que se lhe opõe, de invasão da competência privativa da União para legislar sobre direito processual" (Constituição, art. 22, I). (STF, ADI 2212 MC, Rel. Min. Octavio Gallotti, Tribunal Pleno, julgado em 25/05/2000, DJ 30/03/2001).

${ }^{70}$ Votaram pela improcedência da ADI: Ellen Gracie, Nelson Jobim, Carlos Velloso, Ayres Britto, Marco Aurélio e Sepúlveda Pertence.

71 "Ação direta de inconstitucionalidade: dispositivo do Regimento Interno do Tribunal de Justiça do Estado da Paraíba (art. 357), que admite e disciplina o processo e julgamento de reclamação para preservação da sua competência ou da autoridade de seus julgados: ausência de violação dos artigos 
Portanto, pode-se dizer que, conforme a jurisprudência atual do STF, a reclamação estaria juridicamente comportada na área do direito de petição, previsto no art. $5^{\circ}, \mathrm{XXXIV}, a$, da Constituição Federal.

\subsection{Incidente processual}

Há uma corrente que classifica reclamação como um incidente processual, ou seja, um simples desdobramento do processo originário. EGAS DIRCEU MONIZ DE ARAGÃO, ao defender a tese, explicara que o remédio não objetivaria a composição de um conflito de interesses, o que seria típico da ação, concluindo por enquadrá-la nos limites de um incidente processual, não podendo considerá-la medida administrativa ou recurso:

"A reclamação, longe de ser uma ação ou um recurso, é um incidente processual, provocado pela parte ou pelo Procurador-Geral, visando a que o Supremo Tribunal imponha a sua competência, quando usurpada, explícita ou implicitamente, por outro qualquer tribunal ou juiz". ${ }^{72}$

125, caput e $\S 1^{\circ}$ e 22, I, da Constituição Federal. 1. O Supremo Tribunal Federal, ao julgar a ADIn 2.212 (Pl. 2.10.03, Ellen, DJ 14.11.2003), alterou o entendimento - firmado em período anterior à ordem constitucional vigente (v.g., Rp 1092, Pleno, Djaci Falcão, RTJ 112/504) - do monopólio da reclamação pelo Supremo Tribunal Federal e assentou a adequação do instituto com os preceitos da Constituição de 1988: de acordo com a sua natureza jurídica (situada no âmbito do direito de petição previsto no art. $5^{\circ}, X X I V$, da Constituição Federal) e com os princípios da simetria (art. 125, caput e $\S$ $1^{\circ}$ ) e da efetividade das decisões judiciais, é permitida a previsão da reclamação na Constituição Estadual. 2. Questionada a constitucionalidade de norma regimental, é desnecessário indagar se a colocação do instrumento na seara do direito de petição dispensa, ou não, a sua previsão na Constituição estadual, dado que consta do texto da Constituição do Estado da Paraíba a existência de cláusulas de poderes implícitos atribuídos ao Tribunal de Justiça estadual para fazer valer os poderes explicitamente conferidos pela ordem legal - ainda que por instrumento com nomenclatura diversa (Const. Est. (PB), art. 105, I, e e f). 3.Inexistente a violação do $\S 1^{\circ}$ do art. 125 da Constituição Federal: a reclamação paraibana não foi criada com a norma regimental impugnada, a qual - na interpretação conferida pelo Tribunal de Justiça do Estado à extensão dos seus poderes implícitos possibilita a observância das normas de processo e das garantias processuais das partes, como exige a primeira parte da alínea a do art. 96, I, da Constituição Federal. 4.Ação direta julgada improcedente." (STF, ADI 2480, Rel. Min. Sepúlveda Pertence, Tribunal Pleno, julgado em 02/04/2007, DJ 15/06/2007).

${ }^{72}$ ARAGÃO, Egas Dirceu Moniz de. A correição parcial. São Paulo: Bushatsky, 1969, p. 110 apud PACHECO, José da Silva. O mandado de segurança e outras ações constitucionais típicas. $4^{a}$ ed. rev., atual. e ampl. São Paulo: Ed. Revista dos Tribunais, 2002. 639 p. 


\section{Por sua vez, FREDIE DIDIER JR. e LEONARDO JOSÉ CARNEIRO}

DA CUNHA defendem a não-inclusão da reclamação no grupo dos incidentes processuais:

"Muito embora não haja uma noção precisa e bem delimitada do que seja um incidente processual, é possível estabelecer os seus pressupostos, quais sejam, a) uma situação nova; b) que cai sobre algo que preexiste. O incidente somente existe, se houver, antes, um processo judicial em curso. Surgindo um incidente processual, altera-se o curso do procedimento, podendo haver seu encerramento prematuro, com a extinção do processo, ou um retardamento, com um desvio de rota: o procedimento se suspende ou se altera em razão do incidente. A reclamação constitucional não preenche tais pressupostos, não se enquadrando, portanto, como um incidente processual. Para que haja o incidente, é preciso, como visto, que preexista um processo judicial. Pode haver reclamação constitucional sem que sequer haja processo anterior, mas simples inquérito policial, e ainda assim a competência do tribunal superior pode estar sendo usurpada, 'por se tratar de inquérito que poderia redundar em denúncia contra pessoa que possuía foro privilegiado naquela corte, de modo que a própria atividade inquisitorial havia de ser ali conduzida.,"73

Ademais, a doutrina tem procurado distinguir incidente processual de processo incidente, assentando que, embora a reclamação, por vezes, esteja relacionada um processo, não seria obrigatoriamente um incidente processual. É o que aconteceria, por exemplo, com a ação rescisória e as ações cautelares. $^{74}$

Note-se ainda que a definição de incidente processual pode não ser completa o suficiente a abarcar todas as situações de cabimento do instituto. Isso porque pode haver reclamação sem relação a qualquer processo, como é o caso em que é aberto inquérito por autoridade administrativa em casos em que a apuração de fatos ocorridos é de competência do Tribunal Superior.

\footnotetext{
${ }^{73}$ DIDIER JR., Fredie; CUNHA, Leonardo José Carneiro da. Curso de Direito Processual Civil. Meios de impugnação às decisões judiciais e processo nos tribunais. Salvador: JusPodivm, 2008, p. 443.

${ }^{74}$ MORATO, Leonardo Lins. A reclamação prevista na Constituição Federal. In: ALVIM, Eduardo Pellegrini de Arruda; NERY JR., Nelson; WAMBIER, Teresa Arruda Alvim (Coord.). Aspectos polêmicos e atuais dos recursos. São Paulo: Editora Revista dos Tribunais, 2000, p. 447.
} 


\subsubsection{A posição do STJ}

Diferentemente do Supremo Tribunal Federal, o Superior Tribunal de Justiça sustenta a natureza de incidente processual da reclamação constitucional, razão pela qual, inclusive, não admite a condenação em honorários de sucumbência ${ }^{75}$.

A posição da Corte é a de que, na reclamação, não ocorre a formação de uma relação processual nova, sendo um mero incidente processual, pelo qual se pretende garantir a autoridade da decisão proferida no curso do processo ou preservar a competência do Tribunal.

Nesse sentido, colaciona-se o seguinte aresto:

"CONSTITUCIONAL E PROCESSUAL CIVIL. RECLAMAÇÃO. GARANTIA DA AUTORIDADE DE JULGADO DESTA CORTE IMPUGNADO VIA RECURSO PARA O STF: ADMISSIBILIDADE. DESRESPEITO AO ACÓRDÃO DESTE TRIBUNAL POR PARTE DE AUTORIDADE ADMINISTRATIVA. CONDENAÇÃO EM HONORÁRIOS ADVOCATÍCIOS: IMPOSSIBILIDADE. PROCEDÊNCIA PARCIAL.

(...)

$I V-E$ vedada a condenação em verba de patrocínio na reclamação. A reclamação é apenas um incidente processual. Não dá ensejo à formação de uma nova relação jurídica-processual, tendo em vista a inexistência de citação do reclamado para se defender. Trata-se de mero incidente, através do qual se busca preservar a autoridade a autoridade da decisão proferida no processo, bem como a competência da corte superior a quem cabe julgar determinado recurso interposto no processo.

$V$ - Reclamação julgada parcialmente procedente, sem imposição de condenação em honorários advocatícios. ",76

Assim sendo, a posição jurisprudencial do Superior Tribunal de Justiça adota a tese de que a reclamação é um incidente processual, distinguindo-se,

${ }^{75}$ STJ, Rcl 2017/RS, Rel. Ministra Jane Silva (Desembargadora convocada do TJ/MG), Terceira Seção, julgado em 08/10/2008, DJ 15/10/2008.

${ }^{76}$ STJ, Rcl 502/GO, Rel. Min. Adhemar Maciel, julgado em 14/10/98, DJ 22/03/99. 
por tanto, da posição do Supremo Tribunal Federal, que a insere no campo do direito de petição.

\subsection{Ação autônoma}

A corrente doutrinária majoritária, abalizada por autorizados juristas ${ }^{77}$, confere à reclamação natureza jurídica de ação, embora não seja, essa teoria, a que predomina na jurisprudência dos Tribunais Superiores.

Como de praxe, PONTES DE MIRANDA, à frente de seu tempo, já tratara do assunto, sustentando que "a reclamação não é recurso; é ação contra ato do juiz suscetivel de exame fora da via recursal". ${ }^{78}$

O renomado tratadista JOSÉ DA SILVA PACHECO, o primeiro jurista brasileiro a dar enfoque ao estudo da reclamação, aduz:

"Trata-se, na realidade, de ação, fundada no direito de que a resolução seja pronuncia pela autoridade judicial competente; de que a decisão já prestada por quem tinha competência para fazê-lo tenha plena eficácia, sem óbices indevidos; $e$

\footnotetext{
${ }^{77}$ PACHECO, José da Silva. O mandado de segurança e outras ações constitucionais típicas. $4^{\mathrm{a}}$ ed. rev., atual. e ampl. São Paulo: Editora Revista dos Tribunais, 2002, p. 618-623. ALVIM, Eduardo Arruda. Do cabimento de reclamação pelo descumprimento de súmula vinculante à luz da Lei ${ }^{\circ}$ 11.417/2006. Revista Forense. Rio de Janeiro: Forense, v. 394, nov./dez. 2007, p. 60-62. DIDIER JR., Fredie; CUNHA, Leonardo José Carneiro da. Curso de direito processual civil: meios de impugnação às decisões judicias e processo nos tribunais, vol. 3. $6^{\mathrm{a}}$ ed. Salvador: JusPodvim, p.440-444. MORATO, Leonardo Lins. A reclamação prevista na Constituição Federal. In: ALVIM; Eduardo Pellegrini de Arruda et al (Coord.). Aspectos polêmicos e atuais dos recursos. São Paulo: Editora Revista dos Tribunais, 2000, p.444-448. ANJOS, João Miguel Coelho dos. Reclamação constitucional. In: FÉRES, Marcelo Andrade; CARVALHO, Paulo Gustavo M. (Coord.). Processo nos Tribunais Superiores: de acordo com a Emenda Constitucional n. 45/2004. São Paulo: Saraiva, 2006, p. 36-41. DANTAS, Marcelo Navarro Ribeiro. Reclamação constitucional no direito brasileiro. Porto Alegre: Sergio Antonio Fabris Editor, 2000, p. 459-470. SANTOS, Alexandre Moreira Tavares dos. Da reclamação. Revista dos Tribunais. São Paulo: Ed. Revista dos Tribunais, ano 92, v. 808, fev. 2003, p.149-151.

${ }^{78}$ PONTES DE MIRANDA, Francisco C. Comentários ao Código de Processo Civil - tomo V. Rio de Janeiro: Forense, 1974, p. 384 apud PACHECO, José da Silva. O mandado de segurança e outras ações constitucionais típicas. $4^{\mathrm{a}}$ ed. rev., atual. e ampl. São Paulo: Editora Revista dos Tribunais, 2002. P. 622 .
} 
de que se eliminem os óbices ou se elidam os estorvos que se antepõem, se põem ou se pospõem à plena eficácia das decisões ou à competência para decidir. "79

Assegura-se que a reclamação é ação, por se adequar somente a este tipo jurídico, resultado de uma atividade de exclusão das demais classificações existentes. $^{80}$

Para MARCELO RIBEIRO NAVARRO DANTAS, que adota a classificação trinária das tutelas processuais, a reclamação é uma ação de conhecimento, vez que se busca uma tutela cognitiva, submetida à cognição exauriente, embora reconheça que, utilizada a classificação quinária das sentenças, tratar-se-ia de ação mandamental. ${ }^{81}$

Na visão de PONTES DE MIRANDA, a ação de reclamação pode ser constitutiva negativa ou mandamental, dependendo da hipótese em que seu cabimento esteja fundamentado. ${ }^{82}$

De outro lado, há quem defenda que a reclamação não significaria o exercício da jurisdição, pois a prestação jurisdicional já teria sido conseguida anteriormente, cuidando-se, em âmbito reclamacional, apenas da efetivação da tutela jurisdicional preteritamente obtida. Portanto, como o direito de ação implicaria no exercício da jurisdição, afastar-se-ia a natureza de ação ${ }^{83}$.

\footnotetext{
${ }^{79}$ PACHECO, José da Silva. O mandado de segurança e outras ações constitucionais típicas. $4^{\mathrm{a}}$ ed. rev., atual. e ampl. São Paulo: Editora Revista dos Tribunais, 2002, p. 623.

${ }^{80}$ DANTAS, Marcelo Navarro Ribeiro. Reclamação constitucional no direito brasileiro. Porto Alegre: Sergio Antonio Fabris Editor, 2000, p. 459.

${ }^{81}$ DANTAS, Marcelo Navarro Ribeiro. Reclamação constitucional no direito brasileiro. Porto Alegre: Sergio Antonio Fabris Editor, 2000, p. 463-465.

${ }^{82}$ PACHECO, José da Silva. O mandado de segurança e outras ações constitucionais típicas. $4^{\mathrm{a}}$ ed. rev., atual. e ampl. São Paulo: Editora Revista dos Tribunais, 2002, p. 622.

${ }^{83}$ GRINOVER, Ada Pellegrini; GOMES FILHO, Antonio Magalhães; FERNANDES, Antonio Scarance. Recursos no processo penal. $6^{a}$ ed. rev, atual. e ampl. São Paulo: Editora Revista dos Tribunais, 2009, p. 337.
} 
Negando também a natureza jurídica de ação, alega-se que a reclamação não instauraria nova relação jurídico-processual, mas estaria adstrita a uma relação jurídica principal. ${ }^{84}$

\subsection{Recurso ou sucedâneo recursal}

O conceito clássico de recurso é da lavra de JOSÉ CARLOS BARBOSA MOREIRA que o definiu como sendo o "remédio voluntário idôneo a ensejar, dentro do mesmo processo, a reforma, a invalidação, o esclarecimento ou a integração de decisão judicial que se impugna" ${ }^{85}$.

JOSÉ FREDERICO MARQUES, embora inicialmente a tenha definido simplesmente como medida de Direito Processual Constitucional ${ }^{86}$, elaborou parecer opinando pela natureza recursal da reclamação. ${ }^{87}$

Já ALCIDES DE MENDONÇA LIMA vislumbrava a reclamação como um sucedâneo recursal. Sucedâneo recursal é um instrumento processual que, ainda que formalmente não seja um recurso, comporta-se como se assim fosse, em razão de sua finalidade. ${ }^{88}$

$\mathrm{Na}$ verdade, essa vertente doutrinária, ainda que em outro momento lecionada por grandes processualistas, deve ser afastada, em razão da própria

\footnotetext{
${ }^{84}$ Conforme precedentes do STJ, anteriormente mencionados.

${ }^{85}$ MOREIRA, José Carlos Barbosa. Comentários ao Código de Processo Civil. 11 ed. rev. e atual. Rio de Janeiro: Forense, 2003, v.5, p. 233.

${ }^{86}$ MARQUES, José Frederico. Instituições de direito processual, v. IV. Rio de Janeiro: Forense, p. 391 apud PACHECO, José da Silva. O mandado de segurança e outras ações constitucionais típicas. $4^{a}$ ed. rev., atual. e ampl. São Paulo: Editora Revista dos Tribunais, 2002, p. 620.

${ }^{87}$ PACHECO, José da Silva. O mandado de segurança e outras ações constitucionais típicas. $4^{\mathrm{a}}$ ed. rev., atual. e ampl. São Paulo: Editora Revista dos Tribunais, 2002, p. 620.

${ }^{88}$ GÓES, Gisele Santos Fernandes. Reclamação constitucional. In: DIDIER JR., Fredie (Org.). Ações constitucionais. Salvador: JusPodivm, 2006, p. 503.
} 
jurisprudência, que não admite o uso da reclamação como substitutivo de recurso $^{89}$.

Ademais, abalizada doutrina tem formulado inúmeras críticas à tese, especialmente no que concerne aos princípios informativos da teoria geral dos recursos.

A crítica mais costumeira, e que surge por uma interpretação gramatical da Carta Política, é a de que a reclamação, por ser um instituto de competência originária dos tribunais, não pode ter natureza recursal, vez que, em sua competência originária, estes só julgam ações ou incidentes processuais, nunca recursos ${ }^{90}$.

Além disso, não há previsão expressa na lei incluindo a reclamação no rol dos recursos, como exige o princípio da taxatividade ${ }^{91}$. De acordo com esse princípio, todo recurso deve ser previsto em lei, sendo vedada a sua criação por analogia, interpretação extensiva, norma estadual ou regimental ${ }^{92}$.

Sob outro prisma, a reclamação também se distinguiria dos recursos por não estar vinculada à sucumbência, isto é, não haver necessariamente um revés ao qual se pretenda reverter. Aliás, o reclamante, em regra, visa garantir uma decisão ou aplicação de súmula vinculante que lhe seja favorável ou, ainda, preservar a competência do tribunal ${ }^{93}$.

\footnotetext{
${ }^{89}$ STF, Rcl 6109 ED, Relator Min. CELSO DE MELLO, Tribunal Pleno, julgado em 12/02/2009, DJ $13 / 03 / 2009$.

${ }^{90}$ DANTAS, Marcelo Navarro Ribeiro. Reclamação constitucional. In: FARIAS, Cristiano Chaves; DIDIER JR., Fredie (Coord.). Procedimentos especiais cíveis: legislação extravagante. São Paulo: Saraiva, 2003, p.346-347. No mesmo sentido: GÓES, Gisele Santos Fernandes. Reclamação constitucional. In: DIDIER JR., Fredie (Org.). Ações constitucionais. Salvador: JusPodivm, 2006, p.505.

${ }^{91}$ MORATO, Leonardo Lins. A reclamação prevista na Constituição Federal. In: ALVIM, Eduardo Pellegrini de Arruda et al (Coord). Aspectos polêmicos e atuais dos recursos. São Paulo: Editora Revista dos Tribunais, 2000, p. 447.

${ }^{92}$ DIDIER JR., Fredie; CUNHA, Leonardo José Carneiro da. Curso de Direito Processual Civil. Meios de impugnação às decisões judiciais e processo nos tribunais. Salvador: JusPodivm, 2008, p. 48.

${ }^{93}$ DIDIER JR., Fredie; CUNHA, Leonardo José Carneiro da. Curso de Direito Processual Civil. Meios de impugnação às decisões judiciais e processo nos tribunais. Salvador: JusPodivm, 2008, p. 442.
} 
Nesse passo, na visão de GISELE SANTOS FERNANDES GÓES, a reclamação não pode ser recurso por não objetivar primordialmente reforma (efeito substitutivo) ou invalidação (efeito rescindente), mas o cumprimento de uma decisão anterior ou a salvaguarda da competência do Tribunal, não possuindo também efeito devolutivo, característico dos instrumentos recursais ${ }^{94}$.

Nesse mesmo diapasão, sintetiza, com maestria, CÂNDIDO RANGEL DINAMARCO:

"Não se trata de cassar o ato e substituí-lo por outro, em virtude de algum error in
judicando, ou de cassá-lo simplesmente para que outro seja proferido pelo órgão
inferior, o que ordinariamente acontece quando o ato contém algum vício de ordem
processual. A referência ao binômio cassação-substituição, que é moeda corrente na
teoria dos recursos, apóia-se sempre no pressuposto de que estes se voltam contra
atos portadores de algum erro substancial ou processual, mas sempre atos
suscetíveis de serem realizados pelo juiz prolator, ou por outro - ao contrário dos
atos sujeitos à reclamação, que não poderiam ter sido realizados (a) porque a
matéria já estava superiormente decidida pelo tribunal ou (b) porque a competência
para o ato era deste e não do órgão que o proferiu, nem de outro de seu mesmo
grau, ou mesmo de grau superior no âmbito da mesma Justiça, ou ainda de outra
Justiça." 95

Outrossim, conforme já demonstrado, os recursos são instrumentos processuais aptos a modificar uma decisão judicial anteriormente proferida. Obviamente, apenas secundariamente (de forma reflexa) seus efeitos poderiam atingir, por exemplo, um ato administrativo. Contudo, a reclamação, ao menos em tese, poderia atingir diretamente um ato administrativo, sem que, para isso, tenha de reverter uma decisão jurisdicional anterior ${ }^{96}$.

\footnotetext{
${ }^{94}$ GÓES, Gisele Santos Fernandes. Reclamação constitucional. In: DIDIER JR., Fredie (Org.). Ações constitucionais. Salvador: JusPodivm, 2006, p.505.

${ }^{95}$ DINAMARCO, Cândido Rangel. A reclamação no processo civil brasileiro. In: NERY JR., Nelson; WAMBIER, Teresa Arruda Alvim (Coord). Aspectos polêmicos e atuais dos recursos e de outros meios de impugnação às decisões judiciais. Série aspectos polêmicos e atuais dos recursos, v. 6. São Paulo: Editora Revista dos Tribunais, 2002, p. 101.

${ }^{96}$ No mesmo sentido: DANTAS, Marcelo Navarro Ribeiro. Reclamação constitucional no direito brasileiro. Porto Alegre: Sergio Antonio Fabris Editor, 2000, p. 453.
} 
Com efeito, todo recurso está vinculado a determinado prazo para sua interposição, sob pena de preclusão, característica que o afasta da reclamação, que, a seu turno, não está adstrita a nenhum prazo ${ }^{97}$.

Nesse passo, insta transcrever os ensinamentos de NERI DA SILVEIRA:

"Não nos parece, todavia, se possa reconhecer à reclamação (...) a natureza jurídica de recurso propriamente dito. É que este tem, entre suas notas características, o fato de ser um remedium juris tendente a assegurar à parte vencida um novo julgamento da causa, via de regra por autoridade superior à de quem emanou o ato recorrido. ",98

Por fim, cabe destacar que essa teoria é rejeitada, não só pela doutrina, mas também pela jurisprudência atual, conforme inúmeros precedentes. ${ }^{99}$

\subsection{Remédio processual e outras definições genéricas}

Há uma corrente doutrinária, composta por juristas de renome, que tem proposto uma concepção alternativa da natureza da reclamação, enquadrando o instituto em uma categoria jurídica mais genérica, como a de "remédio processual", evitando, de certa forma, adentrar no núcleo da controvérsia.

Nesse diapasão, HUMBERTO THEODORO JÚNIOR, define a reclamação como um remédio processual específico previsto pela Constituição

\footnotetext{
${ }^{97}$ DANTAS, Marcelo Navarro Ribeiro. Reclamação constitucional no direito brasileiro. Porto Alegre: Sergio Antonio Fabris Editor, 2000, p. 454.

${ }^{98}$ Apud PACHECO, Jose da Silva. O mandado de segurança e outras ações constitucionais típicas. $4^{\mathrm{a}}$ ed. São Paulo: Ed. Revista dos Tribunais, 2002, p. 620.

${ }^{99}$ STF, Rcl 3800 AgR, Rel. Min. ELLEN GRACIE, Tribunal Pleno, julgado em 02/02/2006, DJ $09 / 06 / 2006$.
} 
Federal como um instrumento de denúncia de atos ou decisões que ofendam a competência ou autoridade das decisões dos Tribunais Superiores ${ }^{100}$. Por sua vez, CÂNDIDO RANGEL DINAMARCO, em categorização semelhante, porém menos evasiva, define a reclamação constitucional como um "remédio processual sem natureza recursal". Sem embargo, leciona o processualista:

"A reclamação enquadra-se comodamente na categoria de remédios processuais, que é muito ampla e abriga em si todas as medidas mediante as quais, de algum modo, se afasta a eficácia de um ato judicial viciado, se retifica o ato ou se produz sua adequação aos requisitos da conveniência ou da justiça (Carnelutti). As medidas qualificadas como remédios produzem, conforme o caso, a retificação, a convalidação ou a cassação do ato." 101

Com efeito, apesar de incluir a reclamação no gênero de remédio

processual, trata de afastar esta da espécie recursal:

"Sendo um remédio processual, com toda a segurança a reclamação consagrada no texto constitucional não é todavia um recurso, seja porque não consta entre as modalidades recursais tipificadas em lei (argumento secundário), seja porque não se destina a desempenhar a missão que os recursos têm ". ${ }^{102}$

Outrossim, a categoria também alberga o posicionamento de GISELE SANTOS FERNANDES GÓES:

"A nomenclatura de remédio processual constitucional expressa bem o fenômeno em análise, contudo, prefere-se concluir que é uma garantia constitucional processual, posto que, não basta enunciar o direito, devendo-se ter meios eficientes de assegurá-

100 THEODORO JÚNIOR, Humberto. Curso de direito processual civil - Teoria geral do direito processual civil e processo de conhecimento. $48^{\mathrm{a}}$ ed. Rio de Janeiro: Forense, 2008, p. 639.

${ }^{101}$ DINAMARCO, Cândido Rangel. A reclamação no processo civil brasileiro. In: NERY JUNIOR, Nelson; WAMBIER, Teresa Arruda Alvim (Coord.). Aspectos polêmicos e atuais dos recursos e de outros meios de impugnação às decisões judiciais. Série aspectos polêmicos e atuais dos recursos, v. 6. São Paulo: Editora Revista dos Tribunais, 2002, p. 100.

${ }^{102}$ DINAMARCO, Cândido Rangel. A reclamação no processo civil brasileiro. In: NERY JUNIOR, Nelson; WAMBIER, Teresa Arruda Alvim (Coord.). Aspectos polêmicos e atuais dos recursos e de outros meios de impugnação às decisões judiciais. Série aspectos polêmicos e atuais dos recursos, v. 6. São Paulo: Editora Revista dos Tribunais, 2002, p. 100. 
lo perante qualquer forma de abuso, seja in casu pelo descumprimento de decisão ou Súmula vinculante ou invasão de competência." 103

Por fim, OROZIMBO NONATO há muito conceituou a reclamação como "remédio incomum, excepcional, mas admissível naqueles casos agudos que, pela sua importância, exigem que o tribunal exerça com império ato imediato de função corregedora indispensável"104.

\subsection{Efeitos da definição da natureza jurídica do instituto}

A classificação da reclamação nos moldes de um tipo jurídico produzirá diversas conseqüências ao trato do instituto.

Com efeito, uma vez considerada ação, não se poderia admitir sua disciplina por legislação diversa da federal, vez que se trata de matéria de processo, ex vi do art. 22, I, da Constituição Federal.

Além disso, sua decisão estaria sujeita ao fenômeno da coisa julgada, bem como exigir-se-ia, para sua propositura, o preenchimento das condições da ação e capacidade postulatória. ${ }^{105}$

O STF, ainda que consagre a tese de GRINOVER, tem exigido, em sede reclamacional, a capacidade postulatória ${ }^{106}$, a existência das condições da ação ${ }^{107}$ e tem entendido que a sua decisão está sujeita à coisa julgada ${ }^{108}$.

\footnotetext{
${ }^{103}$ GÓES, Gisele Santos Fernandes, Reclamação constitucional. In: DIDIER JR., Fredie (Org.). Ações constitucionais. Salvador: JusPodivm, 2006, p.505.

${ }^{104}$ Apud PACHECO, José da Silva. O mandado de segurança e outras ações constitucionais típicas. $4^{\mathrm{a}}$ ed. rev., atual. e ampl. São Paulo: Editora Revista dos Tribunais, 2002, p. 618.

105 DIDIER JR., Fredie; CUNHA, Leonardo José Carneiro da. Curso de Direito Processual Civil. Meios de impugnação às decisões judiciais e processo nos tribunais. Salvador: JusPodivm, 2008, p. 444-445.

${ }^{106}$ Rcl 7902 MC, Relator Min. Celso de Mello, julgado em 17/03/2009, DJ 24/03/2009.

${ }^{107}$ STF, Rcl 707 AgR, Relator Min. Marco Aurélio, Relator para acórdão Min. Sepúlveda Pertence, Tribunal Pleno, julgado em 17/12/1997, DJ 20/03/1998.

${ }^{108}$ STF, Rcl 6479 AS, Relator Min. Joaquim Barbosa, julgado em 15/05/2009, DJ 22/05/2009.
} 
Anote-se oportunamente que, se por um lado, nem todo provimento jurisdicional reveste-se da coisa julgada, por outro, tal fenômeno é insuscetível de se manifestar na seara administrativa, o que evidencia certa incoerência na jurisprudência dominante da Corte Constitucional.

Isso porque, no sistema jurídico pátrio, não se admite a figura da coisa julgada administrativa, em razão do princípio da inafastabilidade da jurisdição, razão pela qual, se a reclamação não é medida jurisdicional, sua decisão não poderia se revestir do manto da coisa julgada material.

Além do mais, o STF tem exigido o pagamento de custas para a formulação de reclamação, o que não coaduna com o direito constitucional de petição, que deve ser exercido gratuitamente, sem o pagamento de taxas, na forma do art. $5^{\circ}$, XXXIV, $a$, da Constituição.

No que tange ao STJ, repita-se, aquela Corte tem entendido não ser cabível a condenação em honorários advocatícios em sede de reclamação, em razão da natureza de mero incidente processual, sustentada pelo Tribunal.

\subsection{Conclusões}

Pode-se dizer que, atualmente, a apenas três das correntes apresentadas têm sido dado relevância: a) a que defende a natureza de direito de petição, adotada pelo STF e sustentada por ADA PELLEGRINI GRINOVER; b) aquela que defende a natureza de incidente processual, defendida por EGAS DIRCEU MONIZ DE ARAGÃO e acolhida pelo STJ; e, por fim, c) a que defende a natureza de ação, que parece ser a posição dominante na doutrina.

Todavia, ainda que o debate sobre a natureza jurídica da reclamação esteja longe de um termo, a reclamação vem assumindo um papel de maior relevância na atividade forense, o que certamente resultará em mais estudos e, talvez, menos conclusões - sobre o tema. 
Independentemente de filiação a qualquer das correntes, mister, contudo, assegurar-se uma coesão entre a tese adotada e seus efeitos, o que não parece estar ocorrendo na jurisprudência, especialmente do Supremo Tribunal Federal, que, compreensivelmente, tem sido alvo de críticas de autorizados juristas.

\section{Objeto e cabimento}

A reclamação, cujo objeto é delimitado pela Constituição Federal, resume-se a três hipóteses de cabimento: a) para a preservação de competência do tribunal; b) para a garantia da autoridade das decisões do tribunal; e, c) para garantir a correta aplicação de súmula vinculante.

\subsection{Preservação de competência do tribunal}

A Constituição Federal estabelece a competência originária do Supremo Tribunal Federal e do Superior Tribunal de Justiça para processar e julgar reclamações para a preservação de suas competências (art. 102, I, $l$ e art. 105, $\mathrm{I}, f)$.

Além das competências definidas nos arts. 102 e 105, a Constituição possui inúmeros dispositivos isolados cuja inobservância pode ensejar a formulação de reclamação por usurpação da competência do STF ou do STJ. É o caso, por exemplo, dos arts. 53, §1 $1^{\circ}, 86$ e 96, da Carta Magna.

Sem embargo, a usurpação da competência do tribunal pode acontecer de diversos modos, revelando a amplitude do dispositivo, o que explica a riqueza de julgados em que o tribunal recebe reclamações tendo como objeto exatamente a defesa da competência da Corte. 
Destarte, admite-se reclamação contra ato de Presidente de Tribunal que deixa de remeter, aos Tribunais Superiores, agravo de instrumento interposto em face de decisão denegatória dos recursos de estrito direito (RE ou REsp), na forma do art. 544, do CPC, ou, ainda, quando havia demora injustificada no juízo de admissibilidade desses recursos ${ }^{109}$.

Ressalve-se que, em virtude da nova sistemática trazida pela Lei $\mathrm{n}^{\circ}$ 11.672/2008, poderá a reclamação ser cabível na hipótese em que o Tribunal $a$ quo não observar o art. 543-C, $\S 8^{\circ}$, do CPC.

Com efeito, o STF tem admitido o cabimento de reclamação a fim de destrancar recurso especial ou extraordinário retido, na forma do art. $542, \S 3^{\circ}$, do CPC. Contudo, o STJ, in casu, é a favor do recebimento da reclamação como simples petição ou pela interposição de agravo de instrumento ou requerimento de medida cautelar, por não vislumbrar usurpação de competência da Corte Federal.

Nesse diapasão, é o que se pode extrair dos seguintes arestos do Pretório Excelso:

“RECURSO EXTRAORDINÁRIO RETIDO - ARTIGO 542, § 3, DO CÓDIGO DE PROCESSO CIVIL - EXAME - PROVOCAÇÃO - VIA PRÓPRIA. O meio próprio, perante o Supremo Tribunal Federal, a compelir o juízo primeiro de admissibilidade ao exame do extraordinário é a reclamação. RECURSO EXTRAORDINÁRIO DECISÃO INTERLOCUTÓRIA - ARBITRAGEM - PROCESSAMENTO. Em jogo a jurisdição, ante cláusula em que prevista a solução de conflito de interesse via arbitragem, tudo recomenda a submissão do tema ao Supremo Tribunal Federal. "110

"RECURSO. Agravo de instrumento. Admissibilidade. Retenção de recurso extraordinário. Inteligência do art. 542, $\$ 3^{\circ}$, do CPC. Jurisprudência do STF. Precedentes. Agravo regimental improvido. Contra retenção de recurso

\footnotetext{
109 DIDIER JR., Fredie; CUNHA, Leonardo José Carneiro da. Curso de Direito Processual Civil. Meios de impugnação às decisões judiciais e processo nos tribunais. Salvador: JusPodivm, 2008, p. 449.

${ }^{110}$ STF, AC 212 MC, Rel. Min. MARCO AURÉLIO, Primeira Turma, julgado em 01/06/2004, DJ $10 / 09 / 2004$.
} 
extraordinário na origem, com apoio no art. 542, $\$ 3^{\circ}$, do Código de Processo Civil, é admissivel agravo de instrumento, reclamação ou ação cautelar." 111

Na mesma perspectiva, porém recebendo a reclamação como simples petição, a jurisprudência do STJ assim se manifesta:

"PROCESSO CIVIL. RECLAMAÇÃO. A decisão que determina a retenção do recurso especial $\left(C P C\right.$, artigo 542, $\left.\S 3^{\circ}\right)$ tem natureza meramente administrativa, $e$ pode ser reexaminada a qualquer tempo, seja pelo Tribunal a quo, seja pelo Superior Tribunal de Justiça, por meio de simples petição; a reclamação é inviável porque, decidindo pela retenção, o Presidente do Tribunal a quo pratica ato próprio de suas atribuições, sem qualquer ofensa à autoridade do Superior Tribunal de Justiça. Agravo regimental não provido." 112

Frise-se, por fim, o cabimento de reclamação contra ato de magistrado singular que, usurpando a competência do tribunal, suspende a execução de processo objeto de ação rescisória, sem que haja qualquer decisão do tribunal competente para julgamento da rescisória nesse sentido. ${ }^{113}$

Ademais, admite-se reclamação a fim de preservar a competência do tribunal, mesmo quando o ato usurpador for cometido por autoridade administrativa. $^{114}$

Assim, deve ser observado que para a configuração da usurpação da competência do tribunal não se exige a perpetração de um ato específico para tanto, podendo ocorrer a invasão da competência por mera omissão. Além disso, restou inequívoco que o ato usurpador não se restringe a atos de autoridade judiciária.

\footnotetext{
${ }^{111}$ STF, AI 605687 AgR, Rel. Min. CEZAR PELUSO, Segunda Turma, julgado em 18/12/2007, DJ 29/02/2008.

${ }^{112}$ STJ, AgRg na Rcl 2.402/SP, Rel. Ministro ARI PARGENDLER, Segunda Seção, julgado em 11/04/2007, DJ 23/04/2007.

${ }^{113}$ DIDIER JR., Fredie; CUNHA, Leonardo José Carneiro da. Curso de Direito Processual Civil. Meios de impugnação às decisões judiciais e processo nos tribunais. Salvador: JusPodivm, 2008, p. 450.

${ }^{114}$ STJ, Rcl 1.286/RJ, Rel. Min. Antônio de Pádua Ribeiro, Corte Especial, julgado em 01/10/2003, DJ 20/10/2003, Informativo ${ }^{\circ} 186$.
} 


\subsection{Garantia da autoridade das decisões do tribunal}

A segunda hipótese de cabimento da reclamação instituída pela Constituição Federal tem como objeto a garantia da autoridade das decisões do tribunal (art. 102, I, $l$ e art. 105, I, f).

Note-se que, quando a Carta Política fala em garantir a autoridade do decisum, nada mais é do que dar efetividade à tutela jurisdicional que, por algum motivo alheio à vontade do Tribunal prolator, não vem sendo cumprida, conforme anteriormente determinado. É imprescindível que haja correlação entre o desrespeito alegado e a decisão específica do tribunal, a fim de justificar a via reclamatória.

Desta forma, é incabível reclamação formulada com base em simples divergência entre o ato impugnado e orientação jurisprudencial dominante do tribunal, sem conteúdo normativo. Nesse diapasão, colaciona-se o seguinte julgado:

"PROCESSUAL CIVIL. RECLAMAÇÃO. COMPETENNCIA DOS JUIZADOS ESPECIAIS ESTADUAIS. DEMANDAS RELATIVAS À LEGITIMIDADE DA COBRANCA DA TARIFA DE ASSINATURA BÁSICA DE TELEFONIA. DECISÕES DE JUIZADO EM DESCONFORMIDADE COM A JURISPRUDÊNCIA DO STJ.

1. A Reclamação não é via adequada para controlar a competência dos Juizados Especiais.

2. Igualmente inadequada a via da reclamação para sanar a grave deficiência do sistema normativo vigente, que não oferece acesso ao STJ para controlar decisões de Juizados Especiais Estaduais contrárias à sua jurisprudência dominante em matéria de direito federal, permitindo que tais Juizados, no âmbito da sua competência, representem a palavra final sobre a interpretação de lei federal.

3. Agravo regimental a que se nega provimento. "115

Por outro lado, é pacífico o cabimento da reclamação para garantir a autoridade da decisão de tribunal em virtude de violação por ato judicial, seja

\footnotetext{
${ }^{115}$ STJ, AgRg na Rcl 2.704/SP, Rel. Ministro TEORI ALBINO ZAVASCKI, Primeira Seção, julgado em 12/03/2008, DJe 31/03/2008.
} 
em processos objetivos ou subjetivos. É tipicamente o que acontece quando o juiz singular procede à execução de julgado em forma diferente da determinada pelo Tribunal Superior em sua decisão. ${ }^{116}$

\subsubsection{Reclamação contra ato judicial transitado em julgado: a súmula 734 do STF}

A jurisprudência pacífica no STF e no STJ não admite o cabimento de reclamação em face de decisão que tenha transitado em julgado. Com base nessa antiga orientação, o STF editou a sua súmula $734 .{ }^{117}$

A idéia é não se permitir que a reclamação faça as vezes de ação rescisória, que é o instrumento legal específico capaz de desconstituir o fenômeno da coisa julgada, prezando-se pelo valor segurança nas relações jurídicas. ${ }^{118}$

\subsubsection{Reclamação como sucedâneo de recurso ou ação impugnativa específica}

A jurisprudência e a doutrina têm sido uníssonas quanto ao nãocabimento da reclamação como sucedâneo de recurso ou de qualquer ação impugnativa cabível no caso concreto.

\footnotetext{
${ }^{116}$ MORATO, Leonardo Lins. A reclamação prevista na Constituição Federal. In: ALVIM, Eduardo Pellegrini de Arruda; NERY JR., Nelson; WAMBIER, Teresa Arruda Alvim (Coord.). Aspectos polêmicos e atuais dos recursos. São Paulo: Editora Revista dos Tribunais, 2000, p. 443.

${ }^{117}$ STJ, Rcl 1.576/PB, Rel. Min. Laurita Vaz, Terceira Seção, julgado em 29/10/2008, DJe 05/11/2008.

118 DIDIER JR., Fredie; CUNHA, Leonardo José Carneiro da. Curso de Direito Processual Civil. Meios de impugnação às decisões judiciais e processo nos tribunais. Salvador: JusPodivm, 2008, p. 456.
} 
O saudoso PONTES DE MIRANDA há muito já lecionara sobre a impossibilidade do cabimento de reclamação quando possível a interposição de recurso. ${ }^{119}$

No mesmo diapasão do grande mestre, ensina CASSIO SCARPINELLA BUENO:

"Dada a sua específica finalidade, não é correto o emprego da reclamação como sucedâneo de outras medidas impugnativas das decisões jurisdicionais, tenham natureza de "recurso" ou de "ação". (...) A reclamação não pode, em suma, pretender fazer as vezes do recurso que eventualmente caiba da decisão jurisdicional, dadas as especificidades de suas hipóteses de cabimento. Ela não se volta para a constatação do acerto ou do desacerto de decisões jurisdicionais, mas, apenas e tão-somente, à verificação se elas observam, ou não, os limites que lhes são impostos pelos Tribunais Superiores. "120

Cumpre esclarecer que a reclamação não se presta ao exame da decisão para restringir, invalidar, corrigir ou ampliá-la, o que é o escopo dos recursos, mas, sim, a preservação da competência de tribunal, a garantia da autoridade de suas decisões ou o cumprimento de enunciado sumular de caráter vinculante. ${ }^{121}$

\subsubsection{Reclamação e o princípio da instrumentalidade das formas}

O STF, que tem limitado a abrangência do instituto, tem entendido pela impossibilidade de aplicação do princípio da fungibilidade em sede de

\footnotetext{
${ }^{119}$ MIRANDA, Pontes de. Comentários. $3^{\mathrm{a}}$ ed. Rio de Janeiro: Forense, 1987, vol. IV, p.71 apud CRETELLA JÚNIOR, José. Comentários à Constituição Brasileira de 1988. $2^{\mathrm{a}}$ ed. Rio de Janeiro: Forense Universitária, 1993, p. 3093.

120 BUENO, Cássio Scarpinella. Curso sistematizado de direito processual civil, 5: recursos, processos, e incidentes nos tribunais, sucedâneos recursais: técnicas de controle das decisões jurisdicionais. São Paulo: Saraiva, 2008, p. 425-426.

${ }^{121}$ STJ, Rcl 2.912/SP, Rel. Min. Jorge Mussi, Terceira Seção, julgado em 15/12/2008, DJe 13/02/2009.
} 
reclamação, quando o instrumento legal cabível for recurso ou outra medida impugnativa $^{122}$. Nesse sentido:

"RECLAMAÇ̃̃O. DECISÃO QUE JULGOU DESERTO AGRAVO DE INSTRUMENTO. NÃO CABIMENTO. AGRAVO REGIMENTAL DESPROVIDO. Esta Corte firmou o entendimento no sentido de que compete ao tribunal a quo decretar a deserção de agravo de instrumento, cabendo, dessa decisão, impugnação por meio de novo agravo de instrumento e não por reclamação. Precedentes. Inviável a aplicação do princípio da fungibilidade, tendo em vista que os pressupostos da reclamação são específicos e distintos dos pressupostos do agravo de instrumento. Agravo regimental desprovido." 123

Entretanto, há interessante aresto na jurisprudência do STJ recebendo, como reclamação, notícia-crime enviada pelo então Presidente do Tribunal de Justiça do Rio de Janeiro, que informava sobre inquérito em que figurava como investigado Desembargador do mesmo Tribunal estadual. ${ }^{124}$

\subsubsection{Reclamação contra ato de autoridade administrativa que afronta a autoridade de decisão do Tribunal proferida em processo subjetivo}

A questão ora trazida cinge-se à possibilidade de se impugnar, pela via reclamatória, ato de autoridade administrativa que se traduza em violação à decisão judicial proferida pelo Tribunal em determinado processo subjetivo.

$A b$ initio, impõe esclarecer que não há consenso jurisprudencial sobre o assunto, verificando-se julgados, tanto do STF como do STJ, que levam,

\footnotetext{
122 BUENO, Cássio Scarpinella. Curso sistematizado de direito processual civil, 5: recursos, processos, e incidentes nos tribunais, sucedâneos recursais: técnicas de controle das decisões jurisdicionais. São Paulo: Saraiva, 2008, p. 426. Precedente: STF, Pleno, Rcl-ED 4.395/SP, rel. Min. Cezar Peluso, j. Un. 29/11/2006, DJ 2/2/2007.

${ }^{123}$ STF, Rcl 4294 AgR, Rel. Min. JOAQUIM BARBOSA, Tribunal Pleno, julgado em 11/10/2007, DJ 14/12/2007.

${ }^{124}$ STJ, Rcl 1.286/RJ, Rel. Min. Antônio de Pádua Ribeiro, Corte Especial, julgado em 01/10/2003, DJ 20/10/2003, Informativo ${ }^{\circ} 186$.
} 
algumas vezes, ao cabimento do instituto, e, em outras ocasiões, ao nãocabimento da reclamação.

No seio doutrinário, alguns juristas, dentre os quais FREDIE DIDIER JR. e ALEXANDRE MOREIRA TAVARES DOS SANTOS, sustentam que a reclamação não se presta a impugnar ato da Administração Pública desobediente de decisão judicial prolatada em processo subjetivo, posto que a medida adequada, no caso em tela, seria a apresentação de simples petição ao juízo de primeira instância a quem compete executar as decisões proferidas pelo Tribunal. $^{125}$

A jurisprudência do Supremo Tribunal Federal não tem ajudado a solucionar a questão, uma vez que se nota julgados em ambas direções, razão pela qual, não se pode dizer que haja, no Pretório Excelso, um posicionamento dominante sobre a temática.

Com efeito, é isso o que se constata dos seguintes julgados:

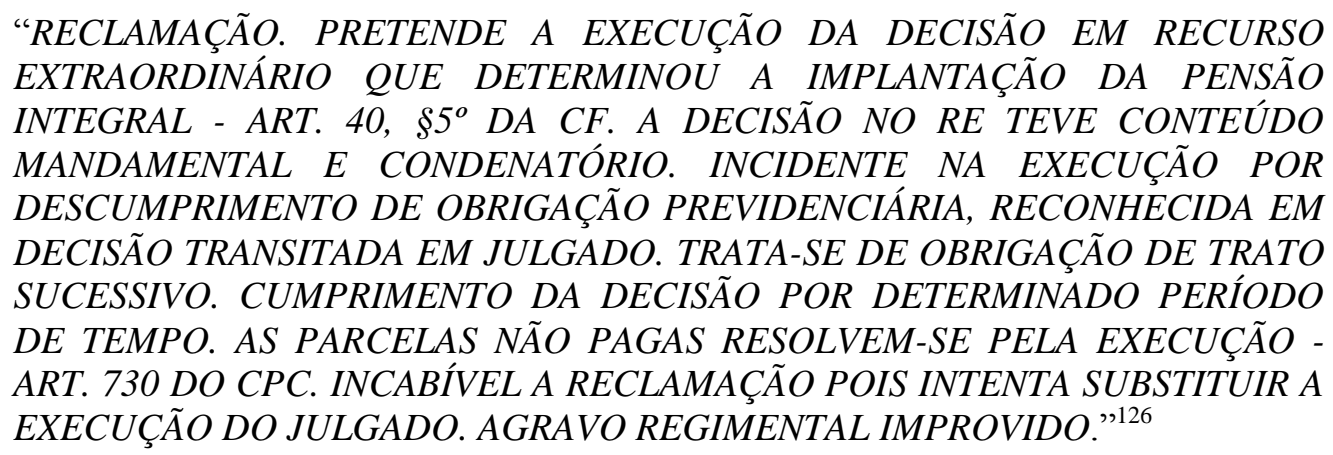

"Reclamação. Ministro do Trabalho e Emprego, que estaria a descumprir o acórdão da $2^{a}$ Turma do Supremo Tribunal Federal, que conheceu e deu provimento ao Recurso Ordinário em Mandado de Segurança n. ${ }^{\circ}$ 23.040, para conceder o writ 2. Incabivel invocar contra o aresto, trânsito em julgado, a existência de "óbices

${ }^{125}$ DIDIER JR., Fredie; CUNHA, Leonardo José Carneiro da. Curso de Direito Processual Civil. Meios de impugnação às decisões judiciais e processo nos tribunais. Salvador: JusPodivm, 2008, p. 452-453. Da mesma forma: SANTOS, Alexandre Moreira Tavares dos. Da reclamação. Revista dos Tribunais. São Paulo: Ed. Revista dos Tribunais, ano 92, v. 808, fev. 2003, p. 131-134.

${ }^{126}$ STF, Rcl 1592 AgR, Rel. Min. Nelson Jobim, Tribunal Pleno, julgado em 02/08/2001, DJ 24/10/2003, Informativo no 235 . 
intransponíveis de ordem legal", inclusive a não mais existência do cargo reclamado. 3. De decisão judicial, trânsita em julgado, resulta, em favor de seus beneficiários, título de direito, que lei posterior ou ato normativo com força de lei não podem prejudicar $\left(C F\right.$, art. $\left.5^{\circ}, X X X V I\right)$. 4. Diante de decisão judicial, com plena eficácia, não cabe à administração ou ao destinatário do cumprimento do que decidido pretender, no âmbito de sua esfera administrativa ou competência, reabrir discussão sobre a matéria, em seu mérito, objeto do decisum, quer com alegações de decadência, quer de existência de litisconsórcio necessário, quer de outra quaestio juris sobre a relação processual instaurada. 5. Acórdão que favorece, tão-somente, os impetrantes do mandado de segurança, que é processo de natureza subjetiva, ficando, assim, o decisum, na sua eficácia, limitado apenas aos autores da ação mandamental. 6. Reclamação julgada procedente para determinar que, em cumprimento ao acórdão do Supremo Tribunal Federal, no Recurso Ordinário em Mandado de Segurança n. ${ }^{\circ} 23.040-9-D F$, no prazo de trinta(30) dias, proceda, sob as penas da lei, a autoridade reclamada, à efetivação dos atos de nomeação dos impetrantes, ora reclamantes, em cargo de Auditor Fiscal do Trabalho, em que se converteu o cargo de Fiscal do Trabalho." 127

De outro ângulo, a jurisprudência do Superior Tribunal de Justiça tem encarado de forma diferente a questão. O Tribunal pacificamente admitia reclamação contra ato de autoridade administrativa que violasse decisão proferida em processo subjetivo, sob o argumento de que a Constituição e a Lei $n^{\circ} 8.038 / 90$ não restringiam o cabimento do instituto. ${ }^{128}$

Todavia, em recentes julgados, o STJ, tem decidido, reiteradamente, pelo não-cabimento de reclamação contra ato de autoridade administrativa que descumpre decisão judicial, em precedentes que demonstram a inclinação da Corte em modificar o seu entendimento pretérito, o que, de certa forma, resta mais coerente, tendo em vista o que esse tribunal tem decidido sobre a natureza jurídica do instituto.

Nesse contexto, encontram-se diversos julgados, dentre os quais, o seguinte:

127 STF, Rcl 1728, Rel. Min. Néri da Silveira, Segunda Turma, julgado em 06/11/2001, DJ 19/12/2001, Informativo ${ }^{\circ} 249$.

${ }^{128}$ STJ, Rcl 2.068/RJ, Rel. Min. Denise Arruda, Rel. para acórdão Min. José Delgado, Primeira Seção, julgado em 13/09/2006, DJ 16/10/2006. Também em: SANTOS, Alexandre Moreira Tavares dos. Da reclamação. Revista dos Tribunais. São Paulo: Ed. Revista dos Tribunais, ano 92, v. 808, fev. 2003, p. 131-132. GÓES, Gisele Santos Fernandes. Reclamação constitucional. In: DIDIER JR., Fredie (Org.). Ações constitucionais. Salvador: JusPodivm, 2006, p. 512. 
"PROCESSUAL CIVIL. AGRAVO REGIMENTAL NA RECLAMAÇÃO. ALEGADO DESCUMPRIMENTO, POR AUTORIDADE ADMINISTRATIVA, DE ACÓRDÃO PROFERIDO POR ESTE TRIBUNAL EM SEDE RECURSAL. INVIABILIDADE DA RECLAMAÇÃO.

1. Não cabe reclamação para combater eventual descumprimento de ordem judicial por autoridade administrativa, exceto nos casos expressamente previstos em lei (arts. 28, parágrafo único, da Lei 9.868/99, e 10, § 3º, da Lei 9.882/99) ou na Constituição (art. 103-A, $\$ 3^{\circ}$, incluído pela EC 45/2004). O Plenário do Supremo Tribunal Federal, ao julgar a Reclamação 831/DF (Rel. Min. Amaral Santos, DJ de 19.2.1971), assentou o entendimento de que "não cabe reclamação, uma vez que não haja ato processual contra o qual se recorra, mas um ato administrativo, que, se violento ou ilegal, tem por remédio ação própria, inclusive o mandado de segurança". Esta Seção, ao julgar o REsp 863.055/GO (Rel. Min. Herman Benjamin, sessão do dia 27.2.2008), endossou o entendimento acima.

2. Mesmo se cabível fosse a reclamação contra decisão proferida no âmbito administrativo, ainda assim não estaria configurado, no caso, o descumprimento do acórdão proferido por esta Corte Superior no julgamento do REsp 842.060/MG, pois o mencionado acórdão limitou-se a confirmar a desconstituição do título executivo impugnado nos embargos à execução fiscal, e o fez pelos mesmos fundamentos adotados nas instâncias ordinárias, a saber, com base no entendimento de que a dívida ativa não-tributária, ao ser inscrita, deve ser precedida de regular procedimento administrativo. A Terceira Seção deste Tribunal, ao julgar o AgRg na Rcl 1.639/DF (Rel. Min. Hamilton Carvalhido, DJ de 13.12.2004, p. 212), enfrentou situação análoga à dos presentes autos, ocasião em que fez consignar na ementa a seguinte orientação: "O ato que determina a instauração de processo administrativo, visando à revisão da concessão de anistia, não importa no descumprimento do acórdão que, estrito aos termos da própria petição inicial, limitou-se a desconstituir $o$ ato que anulou a portaria de concessão de anistia ao reclamante, por não oportunizados o devido processo legal e a ampla defesa, em sede de regular processo administrativo." (grifou-se). Consoante já proclamou a Corte Especial, ao julgar o AgRg na Rcl 2.589/RJ (Rel. Min. Laurita Vaz, DJ de 3.12.2007, p. 246), "'assegurar a autoridade de suas decisões' quer dizer não permitir o descumprimento de ordem direta emanada por este Superior Tribunal de Justiça em seus julgados, o que não se confunde com a pretensão de trazer diretamente a esta Corte questões outras decorrentes de desdobramentos da lide".

3. Agravo regimental desprovido." 129

Do exposto, verifica-se mais uma interessante divergência no campo da reclamação, desta vez em razão do cabimento do instituto em face de ato de autoridade administrativa que descumpra decisão judicial, especificamente em processo subjetivo.

\footnotetext{
129 STJ, AgRg na Rcl 2.918/MG, Rel. Ministra Denise Arruda, Primeira Seção, julgado em 08/10/2008, DJe 28/10/2008.
} 


\subsubsection{A garantia da autoridade das decisões do STF proferidas em controle concentrado de constitucionalidade}

As decisões proferidas pelo Supremo Tribunal Federal, em sede de controle abstrato de constitucionalidade, sejam elas definitivas ou em caráter liminar, geram, em regra, efeitos erga omnes, vinculando todos os órgãos do Poder Judiciário e a Administração Pública, consoante prescrevem os arts. 27 e 28, parágrafo único, da Lei Federal nº 9.868/99.

Anote-se que essas decisões têm natureza dúplice, já que declarada, pelo STF, a constitucionalidade ou inconstitucionalidade do dispositivo impugnado, a sua conclusão, qualquer que seja, produzirá o efeito vinculante supramencionado.

Essas decisões com eficácia erga omnes quando ofendidas justificam o cabimento de reclamação ao STF para garantia da autoridade de sua decisão, independentemente da violação ocorrer por parte de órgão do Poder Judiciário ou pela Administração Pública, em qualquer âmbito federativo.

Todavia, destaque-se que não é cabível a formulação de reclamação a fim de impedir o Poder Legislativo de elaborar norma contrária à decisão proferida pelo STF com efeitos erga omnes, vez que, diante da Separação de Poderes, a eficácia vinculante dessas decisões não tem o condão de atingir o legislador no exercício de sua atividade típica. ${ }^{130}$

\footnotetext{
${ }^{130}$ DIDIER JR., Fredie; CUNHA, Leonardo José Carneiro da. Curso de Direito Processual Civil. Meios de impugnação às decisões judiciais e processo nos tribunais. Salvador: JusPodivm, 2008, p. 453.
} 


\subsubsection{A teoria da transcendência dos motivos determinantes}

A atual composição do STF tem dado nova interpretação a diversos dispositivos constitucionais, realizando verdadeira mutação constitucional, por vezes sob a batuta do eminente ministro GILMAR FERREIRA MENDES.

Com efeito, a teoria dos motivos determinantes permite ao STF ampliar o efeito vinculante das suas decisões prolatadas em âmbito de controle concentrado de constitucionalidade para atingir não só a parte dispositiva do acórdão, mas também a ratio decidendi, isto é, os fundamentos que levaram àquela determinada conclusão, representando, dessa forma, uma exceção à regra consubstanciada no art. 469 , I, do CPC $^{131}$.

Outrossim, encontra-se em debate a relativização do art. 52, X, da CF, para que se autorize, ao STF, a concessão de efeitos erga omnes às decisões proferidas em sede de controle difuso de constitucionalidade ("abstrativização do controle difuso"), sem a necessidade de resolução específica do Senado Federal, aplicando-se, ademais, a teoria da transcendência dos motivos determinantes também na via incidental ${ }^{132}$. Essa questão está sendo resolvida na Rcl 4.335/AC ${ }^{133}$, cujo relator é o próprio Presidente da Excelsa Corte.

O Supremo Tribunal tem admitido reclamações fundadas em decisões que deixam de observar os motivos determinantes que transcenderam dispositivo de decisão em controle abstrato de constitucionalidade, desde que não sejam manejadas para atingir ato normativo do Poder Legislativo.

\footnotetext{
131 BUENO, Cássio Scarpinella. Curso sistematizado de direito processual civil, 5: recursos, processos, e incidentes nos tribunais, sucedâneos recursais: técnicas de controle das decisões jurisdicionais. São Paulo: Saraiva, 2008, p. 424.

132 LENZA, Pedro. Direito constitucional esquematizado. $12^{\text {a }}$ ed. rev., atual. e ampl. São Paulo: Saraiva, 2008, p. 152-156.

133 STF, Rcl 4.335/AC, Rel. Ministro GILMAR MENDES. Votou, até o momento, a favor da inovadora tese apresentada pelo constitucionalista mato-grossense, o Min. Eros Grau. Contra: os Ministros Sepúlveda Pertence e Joaquim Barbosa.
} 
No julgamento, pelo Plenário do Egrégio Tribunal, da Rcl 2.363/PA ${ }^{134}$, sob a relatoria do Ministro GILMAR FERREIRA MENDES, concluiu-se pelo cabimento de reclamação fundada na teoria dos motivos determinantes, vencidos os Ministros MARCO AURÉLIO DE MELO e CARLOS AYRES BRITTO $^{135}$. Confira-se a ementa do aresto:

"Reclamação. 2. Seqüestro de recursos do Município de Capitão Poço. Débitos trabalhistas. 3. Afronta à autoridade da decisão proferida na ADI 1.662. 4. Admissão de seqüestro de verbas públicas somente na hipótese de quebra da ordem cronológica. Não-equiparação às situações de não-inclusão da despesa no orçamento. 5. Efeito vinculante das decisões proferidas em ação direta de inconstitucionalidade. 6. Eficácia que transcende o caso singular. 7. Alcance do efeito vinculante que não se limita à parte dispositiva da decisão. 8. Aplicação das razões determinantes da decisão proferida na ADI 1.662. 9. Reclamação que se julga procedente."

Na mesma linha de raciocínio, manifestou-se o Ministro CELSO DE MELLO, relator da Rcl 5.442/PE ${ }^{136}$, em decisão monocrática:

"Não questiono a afirmação de que se revela possível, para efeito de reclamação, invocar-se a teoria da transcendência dos motivos determinantes, em ordem a reconhecer - consoante já decidido por esta Corte (RTJ 193/513, Rel. Min. GILMAR MENDES - Rcl 1.987/DF, Rel. Min. MAURÍCIO CORREAA - Rcl 2.986-MC/SE, Rel. Min. CELSO DE MELLO) - que o alcance da eficácia vinculante pode estender-se, para além da parte dispositiva do acórdão, também aos próprios fundamentos subjacentes à decisão emanada do Supremo Tribunal Federal".

134 STF, Rcl 2.363/PA, Rel. Min. Gilmar Mendes, PLENÁRIO, julgada em 23/10/2003, DJ 01/04/2005, RTJ 193/513. Outro precedente ocorreu em caso semelhante, cuja reclamação também se baseava na transcendência dos fundamentos da mesma ADI 1.662, decidindo o Supremo por conhecêla: STF, Rcl 1987, Rel. Min. MAURÍCIO CORRÊA, Tribunal Pleno, julgado em 01/10/2003, DJ 21/05/2004.

${ }^{135}$ Os Ministros Marco Aurélio de Melo e Carlos Ayres Britto têm se manifestado diversamente do entendimento majoritário entre os membros do Egrégio Tribunal, inadmitindo a transcendência dos motivos determinantes como fundamento da reclamação.

${ }^{136}$ STF, Rcl 5.442 MC/PE, Rel. Min. Celso de Mello, julgada em 31/08/2007, DJ 06/09/2007. 
Todavia, ainda que pareça ser essa a inclinação da Corte, não se pode falar em consolidação desse entendimento, vez que há registro de julgados que não admitiram reclamações com essa mesma premissa ${ }^{137}$.

\subsection{Garantia do escorreito cumprimento de súmula vinculante}

$\mathrm{O}$ art. 103-A, $\S 3^{\circ}$, da Constituição, introduzido com o advento da Reforma do Judiciário (EC $\mathrm{n}^{\circ} 45 / 2004$ ), consagrou nova modalidade de cabimento da reclamação, prescrevendo o seguinte:

"Art. 103-A. O Supremo Tribunal Federal poderá, de ofício ou por provocação, mediante decisão de dois terços dos seus membros, após reiteradas decisões sobre matéria constitucional, aprovar súmula que, a partir de sua publicação na imprensa oficial, terá efeito vinculante em relação aos demais órgãos do Poder Judiciário e à administração pública direta e indireta, nas esferas federal, estadual e municipal, bem como proceder à sua revisão ou cancelamento, na forma estabelecida em lei.

$\S 3^{\circ}$ Do ato administrativo ou decisão judicial que contrariar a súmula aplicável ou que indevidamente a aplicar, caberá reclamação ao Supremo Tribunal Federal que, julgando-a procedente, anulará o ato administrativo ou cassará a decisão judicial reclamada, e determinará que outra seja proferida com ou sem a aplicação da súmula, conforme o caso."

A seu turno, a Lei $\mathrm{n}^{\mathrm{o}}$ 11.417/06, que regulamenta o dispositivo, também trata da reclamação, nesses termos:

"Art. $7^{\circ}$ Da decisão judicial ou do ato administrativo que contrariar enunciado de súmula vinculante, negar-lhe vigência ou aplicá-lo indevidamente caberá reclamação ao Supremo Tribunal Federal, sem prejuízo dos recursos ou outros meios admissíveis de impugnação.

$\S 1^{\circ}$ Contra omissão ou ato da administração pública, o uso da reclamação só será admitido após esgotamento das vias administrativas.

137 BUENO, Cássio Scarpinella. Curso sistematizado de direito processual civil, 5: recursos, processos, e incidentes nos tribunais, sucedâneos recursais: técnicas de controle das decisões jurisdicionais. São Paulo: Saraiva, 2008, p. 424. 
$\S 2^{o}$ Ao julgar procedente a reclamação, o Supremo Tribunal Federal anulará o ato administrativo ou cassará a decisão judicial impugnada, determinando que outra seja proferida com ou sem aplicação da súmula, conforme o caso."

A súmula vinculante tem efeitos erga omnes em relação aos órgãos do Poder Judiciário e à Administração Pública (art. 2º da Lei no 11.417/06), razão pela qual a reclamação, que tenha como escopo defender enunciado de súmula vinculante, é cabível contra ato de autoridade judicial ou administrativa.

Nesse contexto, cumpre ser observado que a reclamação é cabível quando o ato ou omissão, administrativo ou judicial, contrariar, negar vigência ou aplicar indevidamente súmula vinculante.

A expressão "negar vigência" significa deixar de aplicar a súmula vinculante quando esta deveria ter sido observada. Já "aplicar indevidamente" é aplicar a súmula vinculante para hipótese diversa daquela trazida pelo verbete sumular. Além disso, note-se que "contrariar súmula" é uma expressão mais genérica, capaz de abarca mais situações sociais, no sentido de que a reclamação será cabível sempre que o ato impugnado ofender, de qualquer modo, teor de enunciado vinculante.

Julgada procedente a reclamação, o STF anulará o ato administrativo ou cassará a decisão judicial, determinando a utilização ou não da súmula vinculante no decisum a ser proferido.

\subsubsection{Reclamação e a súmula tradicional}

Não cabe reclamação por violação à súmula tradicional do STF ou do STJ, sem eficácia vinculante, ante a ausência de normatividade do verbete, que somente indica a jurisprudência dominante no Tribunal, sem, contudo, vincular os órgãos jurisdicionais hierarquicamente inferiores. Sobre o tema, vale colacionar o seguinte aresto: 
“CONSTITUCIONAL. RECLAMAÇÃO. ALEGADA VIOLAÇÃO DA AUTORIDADE DE ORIENTAÇÃO JURISPRUDENCIAL SUMULADA. SÚMULA DA JURISPRUDÊNCIA DOMINANTE DO SUPREMO TRIBUNAL FEDERAL. NÃO CABIMENTO. DECISÃO QUE NEGA SEGUIMENTO À RECLAMAÇÃO (ART. 161, PAR. ÚN., DO RISTF). AGRAVO REGIMENTAL. A reclamação constitucional (art. 102, I, l da Constituição) não é meio de uniformização de jurisprudência. Tampouco serve como sucedâneo de recurso ou medida judicial eventualmente cabíveis para reformar decisão judicial. Não cabe reclamação constitucional por alegada violação de entendimento jurisprudencial, independentemente de ele estar consolidado na Súmula da Jurisprudência Dominante do Supremo Tribunal Federal ("Súmula Tradicional"). Hipótese na qual a orientação sumulada tida por ofendida não era vinculante, nos termos do art. 103-A, $\S 3^{\circ}$ da Constituição. Agravo regimental conhecido, mas ao qual se nega provimento." $" 138$

Portanto, assim como não cabe reclamação fundamentada em jurisprudência dominante do Tribunal Superior, não se admite a formulação da medida com base em súmula sem caráter vinculante.

\subsubsection{O esgotamento das vias administrativas como pressuposto de admissibilidade de reclamação}

$\mathrm{O}$ art. $7^{\circ}, \S 1^{\circ}$, da Lei Federal $n^{\circ} 11.417 / 2006$ exige o esgotamento das vias administrativas como requisito de admissibilidade de reclamação contra ato ou omissão de autoridade administrativa que descumpra enunciado de súmula vinculante.

Verifica-se que houve uma opção legislativa por submeter o cabimento do instituto a esse pressuposto, especialmente em decorrência do grande volume de reclamações que seriam processadas e julgadas originariamente pelo Supremo Tribunal com o advento da EC no 45/2004. ${ }^{139}$

A condição imposta pelo dispositivo tem sido alvo de intenso debate doutrinário, em razão da sua aparente contradição com o princípio da

\footnotetext{
138 STF, Rcl 6135 AgR, Relator(a): Min. JOAQUIM BARBOSA, Tribunal Pleno, julgado em 28/08/2008, DJ 20/02/2009.

${ }^{139}$ LOBO, Arthur Mendes. Breves comentários sobre a regulamentação da súmula vinculante. Revista IOB de Direito Civil e Processual Civil. São Paulo: IOB Thomson, ano 8, n. 45, jan./fev. 2007, p. 97.
} 
inafastabilidade da tutela jurisdicional, consubstanciado no art. $5^{\circ}, \mathrm{XXXV}$, da Constituição, vez que, de certa forma, restringiria o acesso ao Poder Judiciário, ao menos pela via reclamatória.

Sem embargo, no campo doutrinário, o consenso parece residir no sentido da constitucionalidade do dispositivo, desde que relativizado em casos especiais, nos quais, o impedimento de se buscar a tutela jurisdicional poderia resultar em dano ao reclamante. ${ }^{140}$

Nesse tocante, FREDIE DIDIER JR., em parceira com LEONARDO JOSÉ CARNEIRO DA CUNHA, com brilhantismo, leciona, in verbis:

"A limitação, embora em tese razoável, e, portanto, constitucional, pode, em concreto, mostra-se exagerada, quando, então, poderá ser afastada, em controle difuso de constitucionalidade, após a aplicação do princípio da proporcionalidade. $O$ condicionamento do exercício do direito à jurisdição pode ser feito pelo legislador, mas não pode significar o aniquilamento deste direito. $O$ exame do interesse de agir, relembre-se, exige a verificação das peculiaridades do caso concreto. Não se justifica constitucionalmente, à luz do direito fundamental à inafastabilidade (art. $5^{\circ}, X X X V$, da CF/88), qualquer regra legal que condicione o exercício do direito de agir a um prévio esgotamento de instâncias extrajudiciais, a pretexto de demonstração do interesse de agir, sem exame das peculiaridades do caso concreto. Não se pode, a priori, definir se há ou não interesse de agir. $O$ legislador não tem esse poder de abstração. Utilidade e necessidade da tutela jurisdicional não podem ser examinadas em tese, independentemente das circunstâncias do caso concreto." ${ }^{141}$

\section{O eminente CÁSSIO SCARPINELLA BUENO sustenta a} constitucionalidade do dispositivo, defendendo, ainda, a possibilidade de manejo de mandado de segurança, in verbis:

\footnotetext{
${ }^{140}$ Mister se faz informar que Eduardo Arruda Alvim, diferentemente, não faz qualquer ressalva ao dispositivo: ALVIM, Eduardo Arruda. Do cabimento de reclamação pelo descumprimento de súmula vinculante à luz da Lei $n^{\circ}$ 11.417/2006. Revista Forense. Rio de Janeiro: Forense, v. 394, nov./dez. 2007, p. 57-58.

${ }^{141}$ DIDIER JR., Fredie; CUNHA, Leonardo José Carneiro da. Curso de Direito Processual Civil. Meios de impugnação às decisões judiciais e processo nos tribunais. Salvador: JusPodivm, 2008, p. 454.
} 
"A exigência é correta e não viola o 'modelo constitucional do direito processual civil' porque impõe à Administração Pública que se comporte de maneira eficiente, como lhe determina o caput do art. 37 da Constituição Federal, manifestando-se em conformidade com as súmulas vinculantes do Supremo Tribunal Federal. Ademais, para resguardar qualquer situação apta a criar ameaça ou lesão ao particular, inclusive decorrente do silêncio abusivo da Administração Pública sobre a observância, ou não, do entendimento daquele Tribunal, é irrecusável a pertinência do uso do 'mandado de segurança'." 142

Na visão de ARTHUR MENDES LOBO, uma vez proferida decisão na esfera administrativa desfavorável ao particular, ou seja, mantendo-se o ato ou omissão supostamente desobediente à súmula vinculante, sendo cabível, de tal decisão, recurso administrativo sem efeito suspensivo, não se poderá afastar o uso da reclamação, ainda que não esgotadas as instâncias administrativas, quando suscetível de causar lesão irreparável ou de difícil reparação. ${ }^{143}$

O STF tem exigido, para o conhecimento da reclamação, que o reclamante comprove ter exaurido todas as vias administrativas, conforme prescreve o art. $7^{\circ}, \S 1^{\circ}$, da Lei $11.417 / 06$, sob pena de extinção da reclamação, sem resolução de mérito, por falta de interesse processual (art. 267, VI, do CPC). ${ }^{144}$

Dessa forma, resta indubitável que deve ser respeitado o dispositivo em tela, tendo em vista a posição da doutrina e da jurisprudência.

\section{Competência}

\subsection{Supremo Tribunal Federal e Superior Tribunal de Justiça}

\footnotetext{
142 BUENO, Cássio Scarpinella. Curso sistematizado de direito processual civil, 5: recursos, processos, e incidentes nos tribunais, sucedâneos recursais: técnicas de controle das decisões jurisdicionais. São Paulo: Saraiva, 2008, p. 380.

${ }^{143}$ LOBO, Arthur Mendes. Breves comentários sobre a regulamentação da súmula vinculante. Revista IOB de Direito Civil e Processual Civil. São Paulo: IOB Thomson, ano 8, n. 45, jan./fev. 2007, p. 9596.

144 STF, Rcl 5600, Rel. Min. Cezar Peluso, decisão monocrática, julgado em 15/09/2008, DJ $22 / 09 / 2008$.
} 
Conforme já demonstrado anteriormente, a previsão da reclamação no seio da Carta Política foi uma inovação trazida com a nova ordem constitucional, resultado da Constituinte de 1987. A reclamação deixou de ser uma criação meramente regimental e foi alçada a norma constitucional, com expressa previsão quanto à competência dos Tribunais Superiores para processamento e julgamento do instituto.

Nesse passo, a Constituição Federal estabelece a competência originária do Supremo Tribunal Federal para processar e julgar a reclamação para a preservação de sua competência (art. 102, I, 1), para garantia da autoridade de suas decisões (art. 102, I, l) e para anulação de ato administrativo ou cassação de decisão judicial que contrariar ou indevidamente aplicar súmula vinculante (art. 103-A, $\S 3^{\circ}$ ). A Carta também institui a competência do Superior Tribunal de Justiça para processar e julgar a reclamação para preservação de sua competência e para garantia da autoridade de suas decisões (art. 105, I, $f$ ).

Todavia, cumpre destacar que o Supremo Tribunal Federal é o único órgão jurisdicional competente para processar e julgar reclamação fundada no art. 103-A, §3ㅇ da Constituição, dispositivo incluído com a Emenda Constitucional $n^{\circ} 45 / 2004$, consoante dispõe o art. $7^{\circ}$, da Lei $n^{\circ} 11.417 / 2006$.

\subsection{Tribunais de Justiça e Tribunais Regionais Federais}

O STF, a partir da ADI 2.212/CE, firmou o entendimento de que os Tribunais de Justiça locais podem processar e julgar reclamações para garantir a autoridade de suas decisões e da garantia de sua competência, em face de órgãos jurisdicionais inferiores, como juízes e órgãos colegiados dos respectivos tribunais locais. 
Assim sendo, nada impede a previsão da reclamação por Constituições Estaduais, leis estaduais de organização judiciária e regimentos internos dos Tribunais de Justiça dos Estados-membros, inexistindo qualquer vício de inconstitucionalidade.

No que tange aos Tribunais Regionais Federais, contudo, sempre foi rechaçada, tendo em vista que os TRFs não se enquadram na estrutura de um Estado-membro, razão pela qual não se poderia aplicar, neste caso, o princípio da simetria, pois o art. 108, da Constituição disporia exaustivamente sobre a sua competência, não prevendo atribuição para julgar reclamação. ${ }^{145}$

Todavia, em recente debate levantado a partir de Questão de Ordem suscitada no REsp 863.05/GO ${ }^{146}$, a Primeira Seção do Superior Tribunal de Justiça concluiu pela possibilidade de previsão da medida no âmbito da Justiça Federal, justificando-se a posição pelo poder implícito dos tribunais. ${ }^{147}$

$\mathrm{O}$ ineditismo desse julgado poderá influenciar a inclusão do instituto nos regimentos internos dos Tribunais Regionais Federais do país, possibilitando, portanto, que esses tribunais façam uso da medida, que já tem previsão nos regimentos internos de diversos Tribunais de Justiça brasileiros.

\footnotetext{
145 DIDIER JR., Fredie; CUNHA, Leonardo José Carneiro da. Curso de Direito Processual Civil. Meios de impugnação às decisões judiciais e processo nos tribunais. Salvador: JusPodivm, 2008, p. 447.

${ }^{146}$ A remessa, a título de questão de ordem, foi indicada no Informativo no 342 , do STJ.

${ }^{147}$ STJ, REsp 863.055/QO, Rel. Min. Herman Benjamin, Primeira Seção, julgado em 27/02/2008, ainda pendente de publicação. Disponível notícia sobre o julgamento em <http://www.stj.gov.br/portal_stj/publicacao/engine.wsp?tmp.area=398\&tmp.texto=86941>. Acesso em 10 maio. 2009.
} 


\subsection{Outros Tribunais}

\subsubsection{Superior Tribunal Militar}

O Superior Tribunal Militar (STM) tem competência originária para processar e julgar reclamação para preservar a integridade da competência ou assegurar a autoridade de seu julgado, consoante o art. $6^{\circ}$, I, $f$, da Lei Federal ${ }^{\circ}$ $8.457 / 92$.

A reclamação poderá ser formulada pelo Ministério Público Militar ou pela Defesa (art. 105, do Regimento Interno do STM), competindo ao Plenário do Tribunal julgar a medida (art. $4^{\circ}, \mathrm{I}, e$, do RISTM).

\subsubsection{Tribunal Superior do Trabalho}

O Tribunal Superior do Trabalho consagrou o instituto da reclamação, nos arts. 190 a 194 de seu Regimento Interno. Todavia, o STF, em julgamento de recurso extraordinário, declarou a inconstitucionalidade dessa previsão regimental, haja vista que somente lei federal poderia instituí-la, por se tratar de Corte Federal, não se aplicando, portanto, o princípio da simetria. ${ }^{148}$

Com efeito, a questão está sendo atualmente debatida em sede de controle abstrato de constitucionalidade, na ADI 3.435, ainda pendente de julgamento, cujo relator é o Min. Marco Aurélio.

148 STF, RE 405031, Rel. Min. Marco Aurélio, Tribunal Pleno, julgado em 15/10/2008, DJe $17 / 04 / 2009$. 


\subsubsection{Tribunal Superior Eleitoral}

O Tribunal Superior Eleitoral prevê a figura da reclamação no art. 15, parágrafo único, V, do seu Regimento Interno. Ocorre que, nesse ponto, têm-se admitido a medida no âmbito do TSE em razão do art. 94, do RITSE estabelecer a aplicação subsidiária do RISTF, o que aconteceria com a reclamação.

\section{Legitimidade}

\subsection{Ativa}

Podem ser sujeito ativo ou reclamante a "parte interessada" ou o Ministério Público, conforme dispõe o art. 13, da Lei 8.038/90. No que tange à expressão "parte interessada", nota-se que se trata de um tipo jurídico aberto, sem qualquer definição pela legislação, sendo indispensável, portanto, a análise da jurisprudência.

Nas reclamações fundadas nas decisões proferidas em processos objetivos, o STF considera legitimado ativo qualquer pessoa que seja atingida pelo descumprimento da decisão com efeitos erga omnes ou do enunciado de súmula vinculante. Nesse diapasão, destaca-se o seguinte julgado:

"QUESTÃO DE ORDEM. AÇÃO DIRETA DE INCONSTITUCIONALIDADE. JULGAMENTO DE MÉRITO. PARÁGRAFO ÚNICO DO ARTIGO 28 DA LEI 9868/99: CONSTITUCIONALIDADE. EFICÁCIA VINCULANTE DA DECISÃO. REFLEXOS. RECLAMAÇÃO. LEGITIMIDADE ATIVA. 1. É constitucional lei ordinária que define como de eficácia vinculante os julgamentos definitivos de mérito proferidos pelo Supremo Tribunal Federal em ação direta de inconstitucionalidade (Lei 9868/99, artigo 28, parágrafo único). 2. Para efeito de controle abstrato de constitucionalidade de lei ou ato normativo, há similitude substancial de objetos nas ações declaratória de constitucionalidade e direta de inconstitucionalidade. Enquanto a primeira destina-se à aferição positiva de constitucionalidade a segunda traz pretensão negativa. Espécies de fiscalização 
objetiva que, em ambas, traduzem manifestação definitiva do Tribunal quanto à conformação da norma com a Constituição Federal. 3. A eficácia vinculante da ação declaratória de constitucionalidade, fixada pelo $\S 2^{\circ}$ do artigo 102 da Carta da República, não se distingue, em essência, dos efeitos das decisões de mérito proferidas nas ações diretas de inconstitucionalidade. $4 . \quad \underline{\text { Reclamacãáo. }}$ Reconhecimento de legitimidade ativa ad causam de todos que comprovem prejuízo oriundo de decisões dos órgãos do Poder Judiciário, bem como da Administracão Pública de todos os níveis, contrárias ao julgado do Tribunal. Ampliacão do conceito de parte interessada (Lei 8038/90, artigo 13). Reflexos processuais da eficácia vinculante do acórdão a ser preservado. 5. Apreciado o mérito da ADI 1662-SP (DJ de 30.08.01), está o Município legitimado para propor reclamação. Agravo regimental provido." 149 (grifo nosso)

Deve ser, não obstante, acrescentado que nem sempre foi essa a posição da Corte Maior. O Tribunal considerava como parte interessada para a formulação de reclamação apenas aquelas pessoas a quem a lei atribuía legitimação para a propositura de $\mathrm{ADI}, \mathrm{ADC}$ ou $\mathrm{ADPF}^{150}$. Porém, conforme já salientado, com relação a processos objetivos, essa não é mais a posição do Supremo Tribunal Federal.

No entanto, nos casos em que não há decisão com efeitos erga omnes, a interpretação dada pela jurisprudência tem sido restritiva, a fim de admitir, na figura de reclamante, somente quem for parte no processo originário e o terceiro juridicamente interessado. ${ }^{151}$

Com relação à hipótese, colaciona-se os seguintes arestos:

"AGRAVO REGIMENTAL EM RECLAMAÇÃO. RECLAMAÇÃO POR SUPOSTA AFRONTA A DECISÕES PROFERIDAS POR ESTA CORTE. ALEGAÇÃO DE AFRONTA À SÚMULA 730 E A DECISÕES PROFERIDAS EM PROCESSOS SUBJETIVOS DOS QUAIS O RECLAMANTE NÃO FOI PARTE. IMPROVIMENTO. I - Não cabe reclamacão, utilizada para garantir a autoridade das decisões proferidas pelo STF, por violacãa a Súmula ou a decisões proferidas em processos

\footnotetext{
149 STF, Rcl 1880 AgR, Rel. Min. Maurício Corrêa, Tribunal Pleno, julgado em 07/11/2002, DJ 19/03/2004.

${ }^{150}$ STF, Rcl 397 MC-QO, Relator(a): Min. Celso de Mello, Tribunal Pleno, julgado em 25/11/1992, DJ 21/05/1993.

151 BUENO, Cássio Scarpinella. Curso sistematizado de direito processual civil, 5: recursos, processos, e incidentes nos tribunais, sucedâneos recursais: técnicas de controle das decisões jurisdicionais. São Paulo: Saraiva, 2008, p. 427.
} 
subjetivos dos quais o reclamante não foi parte. Precedentes. II - Agravo regimental improvido."152 (grifo nosso)

"PROCESSUAL CIVIL. RECLAMAÇÃO. ICMS. SUBSTITUIÇÃO TRIBUTÁRIA. PEÇAS AUTOMOTIVAS. ADIN $N^{o}$ 1890-1. LEGITIMIDADE ATIVA. NÃOCOMPROVAÇÃO. LIMITES DA RECLAMATÓRIA. ART. 105, I, “F”, DA CF/88. EXTINÇÃO.

1. A ausência do inteiro teor do acórdão da egrégia $1^{a}$ Seção inviabiliza a análise da reclamação.

2. Inexistência nos autos de que a reclamante figurou na relacão processual no RMS $n^{\circ}$ 9677/MS, carreando para a sua ilegitimidade ativa.

3. Debate a respeito da aplicabilidade do Decreto Estadual $n^{o} 10.178 / 2000$ e do Termo de Acordo invocados pela reclamante que refoge dos estreitos limites da reclamação (art. 105, I, "f", da CF/88).

4. Extinção da reclamação, sem julgamento do mérito (art. 267, IV e VI, do $C P C) . " 153$ (grifo nosso)

Por outro lado, o Parquet tem legitimação ativa ampla, desde que observadas as funções do cargo, pelo que, no STF, só se admite reclamação apresentada pelo Procurador-Geral da República, e, no STJ, só se admite a medida quando intentada por Subprocurador-Geral da República. ${ }^{154}$

\subsubsection{Capacidade postulatória}

A jurisprudência exige a capacidade postulatória como requisito para o conhecimento da reclamação, logo, indispensável a representação do reclamante por advogado ou defensor público. É o que se verifica da seguinte decisão:

"Reclamação. Ausência de capacidade postulatória da parte reclamante. Somente nos casos em que a lei expressamente excepciona no sentido de admitir capacidade

\footnotetext{
${ }^{152}$ STF, Rcl 5130 AgR, Rel. Min. Ricardo Lewandowski, Tribunal Pleno, julgado em 11/10/2007, DJ 09/11/2007.

153 STJ, Rcl 1590/MS, Rel. Min. José Delgado, Primeira Seção, julgado em 22/09/2004, DJ $25 / 10 / 2004$

154 BUENO, Cássio Scarpinella. Curso sistematizado de direito processual civil, 5: recursos, processos, e incidentes nos tribunais, sucedâneos recursais: técnicas de controle das decisões jurisdicionais. São Paulo: Saraiva, 2008, p. 427-428.
} 
postulatória a quem não tenha os conhecimentos técnicos exigidos pela lei para a propositura das ações e dos instrumentos processuais em geral, é que será possível admiti-la a quem não os possua. Precedente: Rcl 678, Moreira. Reclamação não conhecida." ${ }^{155}$

Por outro lado, quando se tratar de reclamação fundada em descumprimento de decisão com eficácia vinculante proferida em processo objetivo, a parte legitimada para a propositura da respectiva ação, também tem capacidade postulatória para formulação da medida reclamatória. Nesse aspecto:

"RECLAMAÇÃO. GOVERNADOR DO ESTADO. LEGITIMIDADE ATIVA. PRECATÓRIO. PEDIDO CONTRA ATO FUTURO: INADMISSIBILIDADE. OBSERVÂNCIA À DECISÃO PROFERIDA NA ADI 1662-SP. PRETERIÇÃO. SEQÜESTRO DE VERBA PÚBLICA. HIPÓTESE DE CABIMENTO DA MEDIDA CONSTRITIVA. 1. Reclamação por descumprimento de decisão proferida em ação direta de inconstitucionalidade. Governador do Estado. Legitimidade ativa para sua proposicão, tendo em vista sua capacidade postulatória para o ajuizamento de idêntica ação direta. Precedentes. 2. Reclamação. Existência de ato concreto praticado em desacordo com o julgamento da ação direta de inconstitucionalidade. Admissibilidade da ação contra qualquer ato concreto que resulte afronta à competência desta Corte ou à autoridade de suas decisões. Precedente. Nãoconhecimento quanto à pretensão de inibir a autoridade reclamada de expedir novas ordens de seqüestro de verbas públicas, por necessária a existência de fato concreto, contrário à decisão do Supremo Tribunal Federal. 3. Precatório. Pagamento. Preterição de ordem de precedência. Ocorrência. Situação suficiente para motivar o seqüestro de verbas públicas destinadas à satisfação de dívidas judiciais alimentares. Observância à autoridade da decisão proferida na ADI 1662. Reclamação parcialmente conhecida e, na parte conhecida, julgada improcedente." 156

Lançadas tais considerações, aponta-se que a exigência de capacidade postulatória para a reclamação não é coerente com a posição do Supremo Tribunal Federal quanto a natureza jurídica do instituto. Uma vez dito que a

${ }^{155}$ STF, Rcl 729, Rel. Min. Marco Aurélio, Rel. para acórdão: Min. Nelson Jobim, Tribunal Pleno, julgado em 09/09/1998, DJ 24/03/2006.

${ }^{156}$ STF, Rcl 1915, Rel. Min. Maurício Corrêa, Tribunal Pleno, julgado em 04/12/2003, DJ 06/02/2004. 
reclamação residiria no direito constitucional de petição, não há que se falar em capacidade postulatória.

\subsection{Passiva}

O reclamado é o sujeito que figura na parte passiva da reclamação, sendo aquele a quem se imputa o ato que dá ensejo ao cabimento da medida (art. 14, I, da Lei $\mathrm{n}^{\mathrm{o}}$ 8.038/90) ${ }^{157}$. Em tese, pode ser sujeito passivo da reclamação autoridade judicial ou administrativa, ressalvando-se, todavia, a discussão doutrinária quanto a essa última. ${ }^{158}$

\section{Procedimento}

\subsection{Fase postulatória ${ }^{159}$}

A propositura da reclamação fica adstrita à provocação da parte ou do Ministério Público (art. 13 da Lei $\mathrm{n}^{\circ}$ 8.038/90), devendo ser dirigida ao Presidente do Tribunal, e instruída com a prova documental bastante, haja vista que, em sede reclamacional, não há fase instrutória, assim como no rito do mandado de segurança (art. 13, parágrafo único, da Lei 8.038/90; art. 156, parágrafo único, do RISTF; e, art. 187, parágrafo único, do RISTJ).

Assim sendo, a prova documental deve ser pré-constituída, não se admitindo, em regra, a produção de provas ao longo do procedimento da

\footnotetext{
157 STJ, Rcl 2.956/RJ, Rel. Min. Eliana Calmon, Primeira Seção, julgado em 10/12/2008, DJe 09/02/2009.

${ }^{158}$ Nesse sentido, conferir itens 4.2.4 e 4.2.5.

${ }^{159}$ Nomenclaturas propostas em: SANTOS, Alexandre Moreira Tavares dos. Da reclamação. Revista dos Tribunais. São Paulo: Ed. Revista dos Tribunais, ano 92, v. 808, fev. 2003, p.151-162.
} 
reclamação, dado que não é admitida dilação probatória em razão da celeridade do rito.

Todavia, quando a documentação necessária à comprovação do alegado se encontre em repartição ou estabelecimento público, ou em poder de autoridade que se recuse a fornecê-lo por certidão, ALEXANDRE MOREIRA TAVARES DOS SANTOS defende a aplicação, por analogia, do art. $6^{\circ}$, parágrafo único, da Lei 1.533/51, a fim de que caiba ao magistrado ordenar a exibição do documento no prazo de 10 (dez) dias. ${ }^{160}$

Ressalte-se que, nas reclamações de competência do STF, estará legitimado para propô-la, funcionando pelo Parquet, o Procurador-Geral da República, conforme estabelece o art. 156, do RISTF.

Acrescente-se ainda que a reclamação pode ser apresentada em forma eletrônica, com base na Lei $\mathrm{n}^{\mathrm{o}} 11.419 / 2006$, que estabeleceu as diretrizes do processo eletrônico. ${ }^{161}$

Conforme anteriormente analisado, é indispensável a representação por advogado ou defensor público, vez que a jurisprudência exige a capacidade postulatória, sob pena de não conhecimento da reclamação. ${ }^{162}$

Quando possível, a reclamação será encaminhada ao relator da causa principal (art. 13, parágrafo único, Lei 8.038/90), o que é compreensível, em razão da maior proximidade entre o magistrado e a decisão violada. É o caso, principalmente, quando se trata de descumprimento de decisão proferida em controle abstrato de constitucionalidade, quando o relator da ação direta ficará

\footnotetext{
${ }^{160}$ SANTOS, Alexandre Moreira Tavares dos. Da reclamação. Revista dos Tribunais. São Paulo: Ed. Revista dos Tribunais, ano 92, v. 808, fev. 2003, p.156.

161 BUENO, Cássio Scarpinella. Curso sistematizado de direito processual civil, 5: recursos, processos, e incidentes nos tribunais, sucedâneos recursais: técnicas de controle das decisões jurisdicionais. São Paulo: Saraiva, 2008, p.429.

${ }^{162}$ STF, Rcl 729/SP, Rel. Min. Marco Aurélio, Relator para acórdão: Min. Nelson Jobim, Tribunal Pleno, julgado em 09/09/1998, DJ 24/03/2006.
} 
prevento para o julgamento da reclamação ${ }^{163}$. Caso não seja possível, a distribuição será por sorteio.

A fixação da competência interna corporis do órgão competente para julgamento da reclamação será em virtude do ato ou decisão supostamente violado. Com relação ao STF, caberá ao Plenário a reclamação visando a preservação da competência do Tribunal e a reclamação buscando garantir a autoridade das decisões emanadas pelo Tribunal Pleno (art. $6^{\circ}, \mathrm{I}, g$, do RISTF), bem como caberá às Turmas a competência residual para julgamento das demais reclamações (art. $9^{\circ}$, I, $c$, do RISTF). No que tange ao STJ, caberá à Corte Especial o julgamento de reclamações para a preservação de sua competência e para garantia de autoridade de suas decisões (art. 11, X, do RISTJ) e às Seções, as reclamações a fim de preservar sua competência e para garantia de autoridade de decisões suas e das respectivas Turmas (art. 12, III, do RISTJ).

\subsection{Fase ordinatória}

O relator deverá requisitar informações da autoridade a quem for imputada a prática do ato impugnado em 10 (dez) dias, na forma do art. 14, I, da Lei Federal nº 8.038/90.

Alerta-se, no entanto, para o fato de que o RISTF prevê prazo de 5 (cinco) dias para a apresentação das informações requeridas pelo relator. Ocorre que, entre a previsão regimental e o dispositivo de lei federal posterior,

\footnotetext{
163 BUENO, Cássio Scarpinella. Curso sistematizado de direito processual civil, 5: recursos, processos, e incidentes nos tribunais, sucedâneos recursais: técnicas de controle das decisões jurisdicionais. São Paulo: Saraiva, 2008. 429. Cita o autor como precedente jurisprudencial: STF, Rcl 5.470/PA, Rel. Min. Gilmar Mendes, julgamento em 29/02/2008, DJ 10/03/2008.
} 
deve prevalecer o prazo instituído pela Lei $\mathrm{n}^{\circ} 8.038 / 90$, com base no art. $2^{\circ}$, $\S 1^{\circ}$, da LICC. ${ }^{164}$

Embora não se possa falar em revelia e seus efeitos, as informações prestadas têm natureza de verdadeira defesa, assim como ocorre no rito do mandado de segurança. ${ }^{165}$

Registre-se que qualquer interessado, a teor do art. 15, da Lei $\mathrm{n}^{\circ}$ 8.038/90, poderá impugnar o pedido do reclamante, admitindo-se, ainda, a intervenção da parte contrária ao reclamante, que não se beneficie do ato impugnado, na qualidade de assistente litisconsorcial ${ }^{166}$.

Outrossim, o relator poderá ordenar a suspensão do processo ou do ato impugnado, a fim de evitar dano irreparável (art. 14, II, da Lei 8.038/90), independentemente de requerimento expresso pelo reclamante ${ }^{167}$. Nesse ponto diverge a doutrina quanto à natureza jurídica dessa tutela de urgência. Para uns, tratar-se-ia de verdadeira medida liminar com natureza de tutela antecipatória $^{168}$. Para outros, medida acautelatória ${ }^{169}$.

164 DIDIER JR., Fredie; CUNHA, Leonardo José Carneiro da. Curso de Direito Processual Civil. Meios de impugnação às decisões judiciais e processo nos tribunais. Salvador: JusPodivm, 2008, p. 457. SANTOS, Alexandre Moreira Tavares dos. Da reclamação. Revista dos Tribunais. São Paulo: Ed. Revista dos Tribunais, ano 92, v. 808, fev. 2003, p. 154.

${ }^{165}$ SANTOS, Alexandre Moreira Tavares dos. Da reclamação. Revista dos Tribunais. São Paulo: Ed. Revista dos Tribunais, ano 92, v. 808, fev. 2003, p. 157.

${ }^{166}$ DIDIER JR., Fredie; CUNHA, Leonardo José Carneiro da. Curso de Direito Processual Civil. Meios de impugnação às decisões judiciais e processo nos tribunais. Salvador: JusPodivm, 2008, p. 458.

167 DIDIER JR., Fredie; CUNHA, Leonardo José Carneiro da. Curso de Direito Processual Civil. Meios de impugnação às decisões judiciais e processo nos tribunais. Salvador: JusPodivm, 2008, p. 457.

168 DIDIER JR., Fredie; CUNHA, Leonardo José Carneiro da. Curso de Direito Processual Civil. Meios de impugnação às decisões judiciais e processo nos tribunais. Salvador: JusPodivm, 2008, p. 457. SANTOS, Alexandre Moreira Tavares dos. Da reclamação. Revista dos Tribunais. São Paulo: Ed. Revista dos Tribunais, ano 92, v. 808, fev. 2003, p. 158.

169 DANTAS, Marcelo Navarro Ribeiro. Reclamação constitucional no direito brasileiro. Porto Alegre: Sergio Antonio Fabris Editor, 2000, p. 464. MORATO, Leonardo Lins. A reclamação prevista na Constituição Federal. In: ALVIM, Eduardo Pellegrini de Arruda; NERY JR., Nelson; WAMBIER, Teresa Arruda Alvim (Coord.). Aspectos polêmicos e atuais dos recursos. São Paulo: Editora Revista dos Tribunais, 2000, p. 450. 
Aduz ALEXANDRE MOREIRA TAVARES DOS SANTOS que nada impede que o relator conceda ou negue a liminar somente após a apresentação de informações pelo reclamado, ainda que a dicção legal seja no sentido de decidir a tutela quando do despacho da inicial. ${ }^{170}$

Poderá o relator, ainda, requisitar a remessa dos respectivos autos, nos termos do art. 158, do RISTF. ${ }^{171}$

Caberá agravo regimental (ou interno) da decisão do relator que deferir ou indeferir a liminar prevista no art. 14, II, da Lei 8.038/90, consoante o art. 317, do RISTF e o art. 258, do RISTJ.

Acrescente-se que qualquer pessoa poderá impugnar a reclamação apresentada, cuidando-se de intervenção eventual, que prescinde de qualquer chamamento formal. Essa intervenção, além de espontânea, poderá ocorrer em qualquer fase do curso da reclamação. ${ }^{172}$

Por fim, deve ser registrado que é permitido ao relator negar monocraticamente seguimento à reclamação cujo pedido seja manifestamente improcedente, sendo possível interpor o recurso de agravo regimental dessa decisão. ${ }^{173}$

\subsection{Fase pré-final}

Nas reclamações em que não figurar como parte o Ministério Publico, o relator deverá permitir a intervenção do Parquet, no prazo de 5 (cinco) dias,

\footnotetext{
${ }^{170}$ SANTOS, Alexandre Moreira Tavares dos. Da reclamação. Revista dos Tribunais. São Paulo: Ed. Revista dos Tribunais, ano 92, v. 808, fev. 2003, p. 159.

${ }^{171}$ PACHECO, José da Silva. O mandado de segurança e outras ações constitucionais típicas. $4^{\mathrm{a}}$ ed. rev., atual. e ampl. São Paulo: Editora Revista dos Tribunais, 2002, p. 626.

172 GRINOVER, Ada Pellegrini; GOMES FILHO, Antonio Magalhães; FERNANDES, Antonio Scarance. Recursos no processo penal. $6^{\mathrm{a}}$ ed. rev, atual. e ampl. São Paulo: Editora Revista dos Tribunais, 2009, p. 345.

${ }^{173}$ STF, Rcl 5142 AgR/TO, Rel. Min. Marco Aurélio, Tribunal Pleno, julgamento em 29/10/2007, DJe $31 / 01 / 2008$
} 
depois de decorrido o prazo para apresentação de informações pela parte reclamada, na qualidade de custos legis, consoante o art. 16, da Lei $\mathrm{n}^{\circ}$ 8.038/90.

Trata-se de intervenção obrigatória do órgão ministerial, cuja inobservância gera a nulidade dos atos praticados a partir da não intimação do MP, conforme prescreve o art. 246, do CPC.

\subsection{Fase decisória}

Concluindo-se pela procedência do pedido formulado na reclamação, o Tribunal poderá tomar as providências necessárias a fim de dar eficácia a sua decisão ou à sumula vinculante e a garantir sua competência. ${ }^{174}$

$\mathrm{O}$ art. 17, da Lei $\mathrm{n}^{\circ} 8.038 / 90$ prescreve que "o Tribunal cassará a decisão exorbitante de seu julgado ou determinará medida adequada à preservação de sua competência", enquanto que o art. $7^{\circ}, \S 2^{\circ}$, da Lei $\mathrm{n}^{\circ}$ 11.417/06, que disciplina parcialmente a reclamação formulada em face de ato administrativo ou decisão judicial em desconformidade com enunciado de súmula vinculante, estabelece que "o Supremo Tribunal Federal anulará $o$ ato administrativo ou cassará a decisão judicial impugnada, determinando que outra seja proferida com ou sem aplicação da súmula conforme o caso".

Destarte, julgando procedente o pedido reclamacional, o Tribunal poderá cassar a decisão judicial, anular ato administrativo ou determinar as medidas necessárias para preservação de sua competência, inclusive, com a avocação imediata do processo, ou mesmo de inquérito, de sua competência.

O cumprimento da decisão proferida em sede de reclamação deverá ser imediato, a partir da determinação do Presidente do Tribunal,

\footnotetext{
${ }^{174}$ Conforme demonstrado no voto do Ministro MOREIRA ALVES na Rcl 377/PR (STF, Rcl 377/PR, Pleno, Rel. Min. Ilmar Galvão, julgamento em 29/04/92, DJ 30/04/93).
} 
independentemente da lavratura do respectivo acórdão, que poderá ser realizada posteriormente (art. 18, da Lei $\mathrm{n}^{\circ}$ 8.038/90).

\subsection{Recursos}

Em sede de reclamação, cabe a interposição de embargos de declaração, na forma do art. 535, do CPC; agravo regimental ou interno das decisões do relator, na forma, art. 161, parágrafo único, do RISTF; e recurso especial ou extraordinário, quando a reclamação for julgada por tribunais que não STF e STJ. ${ }^{175}$

Observe-se ainda que, quando a reclamação for julgada pelo STJ, caberá, se presentes os pressupostos do art. 102, III, da Constituição Federal, recurso extraordinário para o $\mathrm{STF}{ }^{176}$

\section{Conclusão}

Verificou-se, no presente estudo, a riqueza de debates que permeiam a figura da reclamação constitucional: as diversas correntes acerca da natureza jurídica da medida, a possibilidade ou a impossibilidade de controle de atos praticados por autoridades administrativas pela via reclamatória, a utilização da teoria da transcendência dos motivos determinantes para justificar o cabimento da medida, as questões sobre a legitimação ativa, etc.

175 DIDIER JR., Fredie; CUNHA, Leonardo José Carneiro da. Curso de Direito Processual Civil. Meios de impugnação às decisões judiciais e processo nos tribunais. Salvador: JusPodivm, 2008, p. 458.

176 BUENO, Cássio Scarpinella. Curso sistematizado de direito processual civil, 5: recursos, processos, e incidentes nos tribunais, sucedâneos recursais: técnicas de controle das decisões jurisdicionais. São Paulo: Saraiva, 2008, p. 431-432. 
Observou-se também a evolução do instituto que, de mera construção jurisprudencial, passou a ser instrumento de controle das decisões do STF em sede de controle concentrado de constitucionalidade e de proteção à súmula vinculante.

Essas novas funções assumidas pela reclamação evidenciam a relevância que o instituto assumiu dentro do processo civil-constitucional, o que não pode ser ignorado pela doutrina, principalmente se considerado o significativo aumento de formulação da medida perante o STF.

Paradoxalmente, o estudo do tema, repita-se, de forma genérica, carece de maior profundidade, vez que, por vezes, só é analisado por artigos jurídicos, ainda que se tenha verificado a sua inclusão nas recentes edições de alguns manuais ou cursos de direito processual da lavra de autorizada doutrina, como ADA PELLEGRINI GRINOVER, FREDIE DIDIER JR. e CASSIO SCARPINELLA BUENO.

Além disso, independentemente da tese defendida, deve haver coerência, por parte dos Tribunais, quanto aos seus efeitos da definição da natureza jurídica da medida. Não se pode admitir as atuais discrepâncias, conforme se observou ao longo deste estudo, que não condizem com o alto padrão técnico dos julgados do STF e do STJ.

Por fim, não se pode terminar sem se destacar a utilidade do instituto, que funciona como um instrumento de verdadeira garantia da efetividade da tutela jurisdicional, coibindo o descumprimento ou a inobservância das decisões dos Tribunais, atuando na defesa, não só dos Tribunais, mas do particular lesado por autoridade administrativa ou judiciária. 


\section{Bibliografia}

ALVIM, Eduardo Arruda. Do cabimento de reclamação pelo descumprimento de súmula vinculante à luz da Lei $\mathrm{n}^{\mathrm{o}} 11.417 / 2006$. Revista Forense. Rio de Janeiro: Forense, v. 394, p. 45-69, nov./dez. 2007.

ANJOS, João Miguel Coelho dos. Reclamação constitucional. In: FÉRES, Marcelo Andrade; CARVALHO, Paulo Gustavo M. (Coord.). Processo nos Tribunais Superiores: de acordo com a Emenda Constitucional n. 45/2004. São Paulo: Saraiva, 2006, p. 35-67.

BUENO, Cássio Scarpinella. Curso sistematizado de direito processual civil, 5: recursos, processos, e incidentes nos tribunais, sucedâneos recursais: técnicas de controle das decisões jurisdicionais. São Paulo: Saraiva, 2008. 490 p.

CÂMARA, Alexandre Freitas. Lições de direito processual civil - volume I. $12^{\mathrm{a}}$ ed., rev. e atual. segundo o Código Civil de 2002 e pela Emenda Constitucional 45/2004. Rio de Janeiro: Lumen Juris, 2005. 541 p.

CARVALHO FILHO, José dos Santos. Manual de direito administrativo. $18^{\mathrm{a}}$ ed. Rio de Janeiro: Lumen Juris, 2007. 1080 p.

COSTA, Hélio Rubens Batista Ribeiro. Reclamação nos tribunais estaduais. Revista de Processo. São Paulo: Ed. Revista dos Tribunais, ano 27, v. 105, p. 311-321, jan./mar. 2003.

CRETELLA JÚNIOR, José. Comentários à Constituição Brasileira de 1988. $2^{\mathrm{a}}$ ed. Rio de Janeiro: Forense Universitária, 1993. 3093 p.

DANTAS, Marcelo Navarro Ribeiro. Reclamação constitucional. In: FARIAS, Cristiano Chaves de; DIDIER JR., Fredie (Coord.). Procedimentos especiais cíveis: legislação extravagante. São Paulo: Saraiva, 2003, p. 327-380.

DANTAS, Marcelo Navarro Ribeiro. Reclamação constitucional no direito brasileiro. Porto Alegre: Sergio Antonio Fabris Editor, 2000. 543 p. 
DIDIER JR., Fredie; CUNHA, Leonardo José Carneiro da. Curso de Direito Processual Civil. Meios de impugnação às decisões judiciais e processo nos tribunais. Salvador: JusPodivm, 2008, 577 p.

DINAMARCO, Cândido Rangel. A reclamação no processo civil brasileiro. In: NERY JUNIOR, Nelson; WAMBIER, Teresa Arruda Alvim (Coord). Aspectos polêmicos e atuais dos recursos e de outros meios de impugnação às decisões judiciais. Série aspectos polêmicos e atuais dos recursos, v. 6. São Paulo: Editora Revista dos Tribunais, 2002, p. 99-110.

DINAMARCO, Cândido Rangel. A Reclamação no processo civil brasileiro. Seleções Jurídicas ADV. Rio de Janeiro: COAD, p. 1-4, dez. 2001.

GÓES, Gisele Santos Fernandes. Reclamação constitucional. In: DIDIER JR., Fredie (Org.). Ações constitucionais. Salvador: JusPodivm, 2006, p. 501-522.

GRINOVER, Ada Pellegrini. A reclamação para garantia da autoridade das decisões dos tribunais. Revista Síntese de Direito Penal e Processo Penal. Porto Alegre: Síntese, ano 1, n. 2, p. 11-18, jun./jul. 2000.

GRINOVER, Ada Pellegrini. Da Reclamação. Revista Brasileira de Ciências Criminais. São Paulo: Ed. Revista dos Tribunais, v. 9, n. 38, p. 75-83, abr./jun. 2002.

GRINOVER, Ada Pellegrini; GOMES FILHO, Antonio Magalhães; FERNANDES, Antonio Scarance. Recursos no processo penal. $6^{\mathrm{a}}$ ed. rev, atual. e ampl. São Paulo: Editora Revista dos Tribunais, 2009. 366 p.

LENZA, Pedro. Direito constitucional esquematizado. $12^{\mathrm{a}}$ ed. rev., atual. e ampl. São Paulo: Saraiva, 2008, 811 p.

LOBO, Arthur Mendes. Breves comentários sobre a regulamentação da súmula vinculante. Revista IOB de Direito Civil e Processual Civil. São Paulo: IOB Thomson, ano 8, n. 45, p. 77-101, jan./fev. 2007.

MARINONI, Luiz Guilherme; ARENHART, Sérgio Cruz. Curso de processo civil, volume 2: processo de conhecimento. $6^{a}$ ed. rev., atual. e ampl. São Paulo: Editora Revista dos Tribunais, 2009. 814 p. 
MENDES, Gilmar Ferreira. A reclamação constitucional no Supremo Tribunal Federal: algumas notas. Direito Público. Porto Alegre: Síntese, v. 3, n. 12, p. 21-47, abr./jun. 2006.

MORAES, Alexandre de. Direito constitucional. $21^{\text {a }}$ ed. São Paulo: Atlas, 2007. 994 p.

MOREIRA, José Carlos Barbosa. Comentários ao Código de Processo Civil. 11 ed. rev. e atual. Rio de Janeiro: Forense, 2003, v.5. 786 p.

MORATO, Leonardo Lins. A reclamação prevista na Constituição Federal. In: ALVIM, Eduardo Pellegrini de Arruda; NERY JR., Nelson; WAMBIER, Teresa Arruda Alvim (Coord.). Aspectos polêmicos e atuais dos recursos. São Paulo: Ed. Revista dos Tribunais, 2000, p. 441-452.

PACHECO, José da Silva. A "Reclamação" no STF e no STJ de acordo com a nova Constituição. Revista dos Tribunais. São Paulo: Ed. Revista dos Tribunais, v. 646, ano 78, p. 19-32, ago. 1989.

PACHECO, José da Silva. $O$ mandado de segurança $e$ outras ações constitucionais típicas. $4^{\mathrm{a}}$ ed. rev., atual. e ampl. São Paulo: Ed. Revista dos Tribunais, 2002. $639 \mathrm{p}$.

PEREIRA, Flávio Henrique Unes. Configurada a hipótese de reclamação, estaria inviabilizado, necessariamente, o manejo do mandado de segurança?. Interesse Público. Porto Alegre: Notadez, ano 8, n. 38, p. 123-133, jul./ago. 2006.

SANTOS, Alexandre Moreira Tavares dos. Da reclamação. Revista dos Tribunais. São Paulo: Ed. Revista dos Tribunais, ano 92, v. 808, p.121-166, fev. 2003.

THEODORO JÚNIOR, Humberto. Curso de direito processual civil - Teoria geral do direito processual civil e processo de conhecimento. $48^{\mathrm{a}}$ ed. Rio de Janeiro: Forense, 2008. 871 p.

<www.stf.jus.br>. Acesso em 12 abr. 2009.

<www.stj.jus.br>. Acesso em 13 abr. 2009. 